\title{
Cyprideis torosa (Jones, 1850) in mainland Portugal: what do we know?
}

\author{
M. C. Cabral*, F. Fatela, V. Lopes, M. C. Freitas \& C. Andrade \\ Departamento de Geologia and Instituto Dom Luiz (IDL), Faculdade de Ciências, Universidade de Lisboa, Campo Grande, C6, \\ $4^{\circ}, 1749-016$ Lisboa, Portugal \\ *Correspondence: mccabral@fc.ul.pt
}

\begin{abstract}
The distribution of Recent and Holocene Cyprideis torosa (Jones, 1850) from brackish estuaries and lagoons of mainland Portugal is presented; older Cenozoic C. torosa are also briefly mentioned. Around 550 specimens were found alive, in Melides lagoon (456) and salt marshes from large estuaries (90). Thousands of empty valves and carapaces, with different ornamentation, were found in the lagoon, the estuaries and in Holocene samples from boreholes, in the latter with higher concentration in sediments deposited in lagoons. The modern C. torosa was found living mainly in Melides lagoon, associated with brackish and freshwater ostracod species, in soft mud or muddy sand sediments from quiet zones, with salinities from 4.1 to 15.1 ; it is also found in soft mud to muddy sand sediments whose interstitial waters have salinities from 19.0 to 34.1 , on salt marshes (tidal flat and low marsh) of large estuaries, similar to lagoons, in low hydrodynamic areas, together with other brackish ostracods. The main parameters controlling the distribution of $C$. torosa appear to be the substrate, water dynamics and emersion time, whereas water chemistry is more related to the morphology of valves. In general, $C$. torosa presents the same ecological characteristics in the Holocene and in modern times.
\end{abstract}

Keywords: Ostracods, salt marshes, estuaries, lagoons, Cenozoic, Portugal

Received 5 October 2015; revised 15 March 2016; accepted 20 March 2016

Cyprideis torosa (Jones, 1850) is a widespread brackish-water ostracod species, highly euryhaline, found from almost freshwater to fully marine, even hypersaline (over $60 \%$ ) water, in marginalmarine environments (lagoons, estuaries, deltas, salt marshes, coastal ponds, fjords, etc.) down to a depth of around $30 \mathrm{~m}$ (Athersuch et al. 1989; Meisch 2000). Its presence in inland waters is known only in slightly brackish lakes (Meisch 2000). It also tolerates a wide range of temperature and oxygen conditions; it prefers soft sediments (muddy or sandy mud substrate) where large amounts of organic detritus are present (Heip 1976), but also lives in pure sand and on algae (Athersuch et al. 1989). Heip (1976) refers to its exceptional concentration in some types of sediments, where it can even be the main component. It is known from the Miocene until Recent (Meisch 2000).

In Portugal, C. torosa is common in Recent and Holocene brackish-water coastal environments, both alive and dead, although much more frequently represented by empty valves in lagoons and estuaries. This species is referred to in several papers concerning brackish Holocene and Recent Portuguese ostracods (mixed with marine and also freshwater forms), especially those published after 1999: Paulo \& Moutinho (1983), Hindson \& Andrade (1999), Hindson et al. (1999), Cearreta et al. (2003), Cabral et al. (2006, 2011), Hilbich et al. (2008), Lord et al. (2011), Cabral \& Loureiro (2013), Trog et al. (2013, 2015). In Martins et al.'s (2010) overview about the ostracods living in freshwater Portuguese habitats there is no reference to $C$. torosa.

In this work we present the current distribution of Recent and Holocene C. torosa in mainland Portugal and we examine the biological response of the species to differences in physical and chemical parameters within several estuarine salt marshes and the Melides lagoon. We also compare the modern $C$. torosa assemblages of the Melides lagoon (part of an ongoing work with the aim of characterizing the seasonality signal of modern ostracod faunas and the role of the sandy barrier in the environmental evolution of the lagoon through time) and of the estuarine salt marshes with those found in the Holocene sedimentary records.

The material presented here comes from:

(a) observations of one of the authors (MCC) on Recent ostracods in sediments from different estuaries and lagoons of western Portugal and on Holocene ostracods from long boreholes (several projects led by MCF, FF, CA, some completed, others ongoing, all having as one of their objectives the determination of the ostracod assemblages and their distribution in mainland Portugal);

(b) information from unpublished notes (MCC);

(c) reports of several research projects (MCC);

(d) Master degree theses (all supervised by MCC in the Department of Geology, Faculty of Sciences, University of Lisbon); and

(e) published papers.

Cyprideis torosa is a very ecologically tolerant species, colonizing highly fluctuating and stressed habitats; it was often found in both Recent and Holocene sediments from Portuguese estuaries and lagoons, showing different morphological aspects and in contrasting abundances and associations. This motivated us to compile and discuss the data and try to understand the most important environmental parameters limiting the occurrence and distribution of this species, hoping that this may be useful for researchers working on the same subject.

\section{Study areas}

The studied areas are the same as those reported in Cabral \& Loureiro (2013), except the continental shelf and slope of western Algarve; here we add eleven new samples from the surface sediment layer of Melides lagoon and one borehole taken in Mira river.

Recent material comes from several estuaries of the western Portuguese coast (Fig. 1) and Melides lagoon (Fig. 2): 


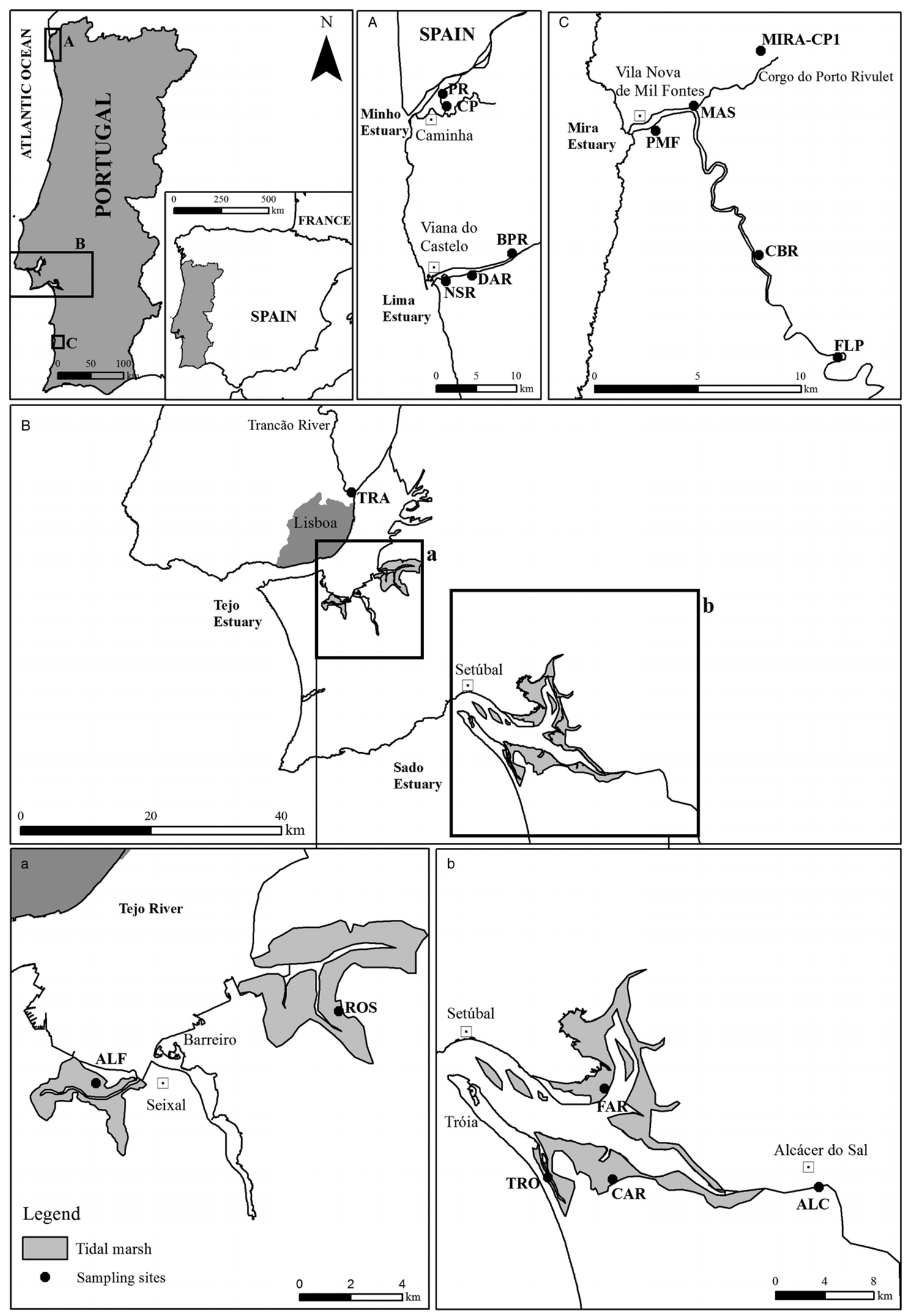

Fig. 1. Location map of the studied transects in the Portuguese estuaries: (A) Minho estuary (CP and PR) and Lima estuary (NSR, DAR, BPR). (B) Tejo and Sado estuaries, with TRA transect indicated in Tejo estuary - (a) Tejo estuary (ALF, ROS), (b) Sado estuary (ALC, CAR, FAR and TRO). (C) Mira estuary (PMF, MAS, CBR and FLP); MIRA-CP1 is a Holocene borehole in Corgo do Porto rivulet. 


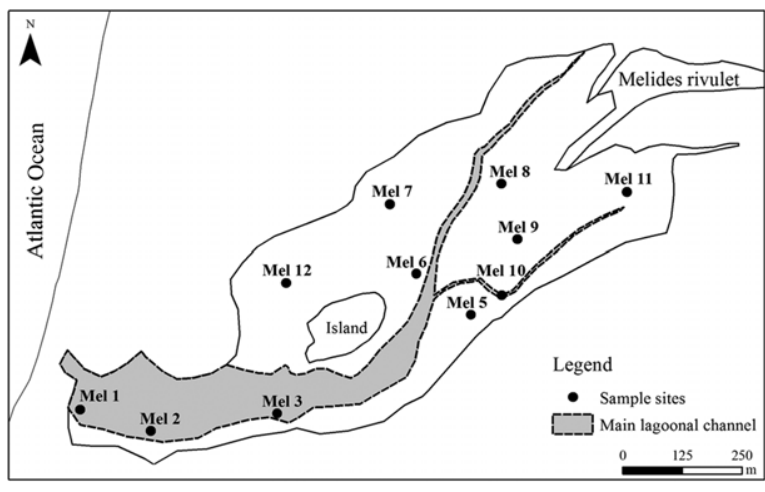

Fig. 2. Location map of the studied sites (surface samples) and of the main channel on Melides lagoon.

- Minho River and Coura tributary -2 transects, 1 in the Coura confluence with the Minho River (CP), 1 in the lower Minho estuary (PR).

- Lima River - 1 transect in the lower estuary (NSR), 2 transects in the mid estuary (DAR and BPR).

- Tejo River and Trancão tributary -2 transects in the lower Tejo estuary (ALF and ROS), 1 transect in the lower Trancão estuary (TRA), $100 \mathrm{~m}$ upstream the confluence with the mid Tejo estuary.

- Sado River -3 transects in the lower estuary (FAR, CAR, TRO), 1 transect in the mid estuary (ALC).

- Mira River -2 transects in the lower estuary (PMF and MAS), 2 transects in the mid estuary (CBR and FLP).

Each transect covered the tidal flat, low marsh (c. Spartina) and high marsh (c. 'Salicornia' and Halimione).

- Melides lagoon (Figs 2 and 3) - 11 sites inside the lagoon, among which 5 sites $(1,2,3,5$ and 10) are located along the southern margin, where the currents are stronger; 3 sites ( 7 , $8,12)$ located on the northern margin, in a sheltered zone; 3 sites $(6,9$ and 11) located in the central-eastern part of the lagoon, also in sheltered conditions, specially site 6 located near a lagoonal island.

- Holocene material comes from several boreholes taken from coastal lagoons and estuaries (Fig. 3). From north to south:

- Pederneira estuary/lagoon, west Portugal - 3 long boreholes in the Recent alluvial plain of Alcoa River, 2 in the inner infilled lagoon (S1 and S2), another in the middle infilled lagoon (S3).

- Sizandro estuary/lagoon, west Portugal - 1 long borehole in the alluvial plain of Sizandro River, around $10 \mathrm{~km}$ from the coast (RS06_1).

- Tejo estuary - 1 long borehole in Lisboa downtown (esteiro da Baixa infilled rivulet), Praça do Comércio (PC).

- Melides lagoon, SW Portugal - 2 long boreholes, one in the alluvial plain of the modern lagoon (MIGM), another in the sand barrier (MB).

- Santo André lagoon, SW Portugal - 1 long borehole in the alluvial plain bordering the modern lagoon (LSA).

- Mira estuary, SW Portugal (Fig. 1) - 1 long borehole in the alluvial plain of Corgo do Porto tributary (MIRA-CP1).

\section{Material and methods}

The forms found in salt marshes were generally collected in muddy sediment or in fine sand or silty sand substrates; the forms from Melides lagoon were collected in sediments varying from sand to mud; at each sampling point in marshes and Melides lagoon, one sample was collected to study the sediment grain size ( $\%$ of sand and mud $=$ silt + clay). Sampling of marshes was undertaken in two different seasons, generally in autumn and spring, in December 2005 and May 2006; exceptions were the Minho estuary sampled in April and October 2011 and the Alfeite salt marsh (Tejo estuary) sampled in the early winter and summer (January and July 2011); Melides lagoon samples were collected during winter (February 2015). In the salt marshes the samples were collected with a cut-off syringe; sediment from Melides lagoon was retrieved using a van Veen grab operated from a boat and, once aboard, the sample was collected as in the salt marshes. Temperature, salinity, dissolved oxygen and $\mathrm{pH}$ were measured using direct-reading probes for estuarine waters, and also in marsh sediment interstitial waters (when enough water was accumulated inside a $40 \mathrm{~cm}$-deep perforated hole, close to each sampling point). In Melides lagoon those parameters were measured at the water surface and bottom at each sampling point; the depth of each sampling point was also noted (Table 1).

Brackish waters were classified using the Venice system.

The samples $\left(30 \mathrm{~cm}^{3}\right.$ each, from three $10 \mathrm{~cm}^{3}$ aliquots of the topmost $1 \mathrm{~cm}$ surface sediment layer, immediately preserved in $70 \%$ alcohol after collection) were washed through a $0.063 \mathrm{~mm}$ sieve, immersed for at least $1 \mathrm{~h}$ in a $\left[1 \mathrm{~g} \mathrm{l}^{-1}\right]$ Rose Bengal solution to facilitate the recognition of the live forms and rewashed to eliminate excess stain; they were then dried in an oven below $50^{\circ} \mathrm{C}$.

Forms were identified as alive when containing the soft parts (appendages) and pink staining due to the Rose Bengal.

The Holocene samples $\left(10 \mathrm{~cm}^{3}\right.$ each) for ostracod analyses were taken only from boreholes (drilled between 1998 and 2009) at $30-50 \mathrm{~cm}$ intervals with higher resolution in clay units and near lithological boundaries. Further laboratory procedures were the same as described for Recent material, without application of Rose Bengal solution.

All the ostracods were picked, both valves and carapaces of juveniles and adults, dead or alive. We considered 1 individual (1 specimen) $=1$ valve or 1 carapace, dead or alive.

The taxa were identified only on the basis of valves and carapaces without soft parts.

Identification of the species found in association with C. torosa were based primarily on Yassini (1969), Barbeito-Gonzàlez (1971), Bonaduce et al. (1976) and Athersuch et al. (1989). For a complete systematic list and ecological characteristics of the living species of the salt marshes, see Cabral \& Loureiro (2013).

All the studied specimens are deposited in the Cabral Collection of the Department of Geology, Faculty of Sciences, University of Lisbon.

\section{Results and discussion}

In the Recent sediments of mainland Portugal Cyprideis torosa was found in Lima, Tejo, Sado and Mira estuaries and in Melides lagoon, generally as empty valves. It was alive in some transects of Tejo and Sado estuaries and in six sites in Melides lagoon. In all of the studied Holocene boreholes (Lisboa - PC; Melides - MB and MIGM; Mira - MIRA-CP1; Pederneira - S1, S2 and S3; Santo André - LSA; Sizandro - RS06_1) and most boreholes described in the literature (Hindson \& Andrade 1999; Hindson et al. 1999; Hilbich et al. 2008; Trog et al. 2013, 2015), C. torosa was present.

\section{Ecology of Recent ostracod fauna}

\section{Estuaries}

In all the Portuguese estuaries tides present a semi-diurnal highmesotidal regime. The range varies between $2 \mathrm{~m}$ during neap waters and almost $4 \mathrm{~m}$ in spring tides but the astronomical tidal levels are often incremented by storm surges (Taborda \& Dias 1991). 


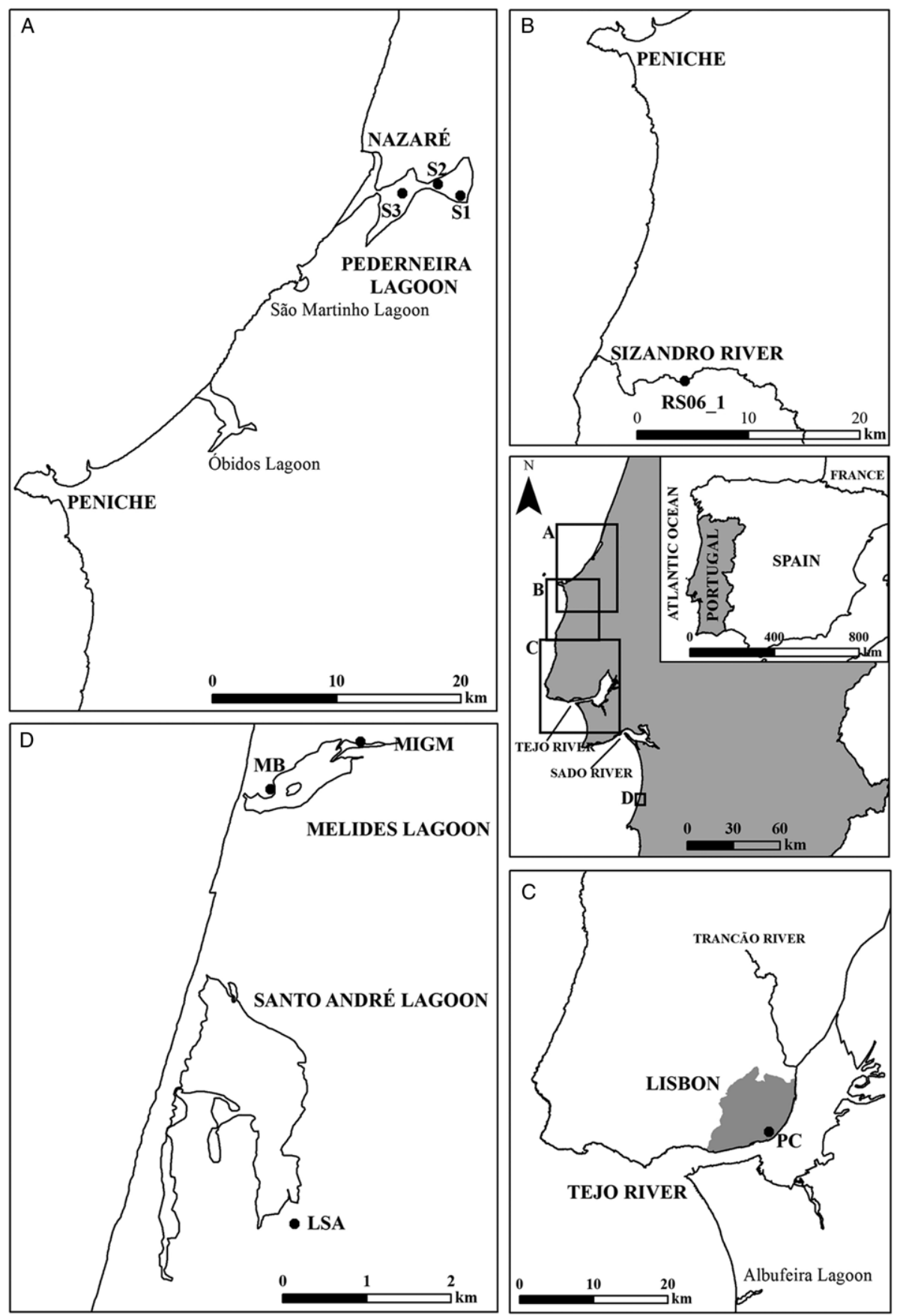

Fig. 3. Location map of the studied Holocene boreholes: (A) Pederneira lagoon (S1-S3); (B) Sizandro river (RS06_1); (C) Tejo estuary (PC); (D) Melides lagoon (MB and MIGM) and Santo André lagoon (LSA).
In the studied salt marshes of the northwestern estuaries we can consider that $C$. torosa is not present. No specimens were found in Minho river and, in Lima river, only one dead adult valve, surely transported, was present in the lower estuary, NSR transect. The same pattern was seen in Mira river, SW Portugal (Loureiro et al. 2009), where only one juvenile, worn, dead valve was found in the lower estuary, PMF transect. These three rivers (Fig. 1), varying in length from $108 \mathrm{~km}$ (Lima river) to $300 \mathrm{~km}$ (Minho river) and in drainage area from $1600 \mathrm{~km}^{2}$ (Mira river) to $17080 \mathrm{~km}^{2}$ (Minho river), have in common a relatively channelled and shallow estuary (maximum depth $c .10 \mathrm{~m}$ ). The flux is relatively stable in the NW: $c$. $300 \mathrm{~m}^{3} \mathrm{~s}^{-1}$ in Minho river (Bettencourt et al. 2003), with an average annual precipitation higher than $1600 \mathrm{~mm}$ and which may reach more than $3500 \mathrm{~mm}$ (e.g. Fatela et al. 2014); c. $70 \mathrm{~m}^{3} \mathrm{~s}^{-1}$ in Lima river (Ramos et al. 2006), with an average annual precipitation of $1300 \mathrm{~mm}$ (Bettencourt et al. 2003); and highly variable in the SW, where the climate has typical Mediterranean characteristics with marked alternating seasons, with an annual precipitation around
$645 \mathrm{~mm}$ (ICNB 2008) and a flux of $0-500 \mathrm{~m}^{3} \mathrm{~s}^{-1}$ in Mira river (ICNB 2008), where yearly average fluvial discharge is around $2.9 \mathrm{~m}^{3} \mathrm{~s}^{-1}$ (MARETEC 2015). The substrate is rich in sands in the NW estuaries, muddy in the Mira river.

The most important characteristic common to the three estuaries is the highly channelled morphology, without sheltered areas, promoting strong tidal currents over the salt marshes, which seems to prevent the presence of $C$. torosa in the estuary and associated salt marshes. It is clear that this species avoids active current waters.

The $325 \mathrm{~km}^{2}$ Tejo estuary, located in the central-southwestern coast of Portugal (Fig. 1) is among western Europe's largest. Its hydrographical basin $\left(81310 \mathrm{~km}^{2}\right)$ has $25666 \mathrm{~km}^{2}$ in Portugal and $55644 \mathrm{~km}^{2}$ in Spain (ARH Tejo 2011). The average annual precipitation in the Tejo basin is $700 \mathrm{~mm}(650 \mathrm{~mm}$ in the Spanish sector, $900 \mathrm{~mm}$ in the Portuguese right shore and $600 \mathrm{~mm}$ in its left shore; ARH Tejo 2011). The fluvial discharge average is around $300 \mathrm{~m}^{3} \mathrm{~s}^{-1}$, but the annual average discharge ranges between $250 \mathrm{~m}^{3} \mathrm{~s}^{-1}$ and $5400 \mathrm{~m}^{3} \mathrm{~s}^{-1}$ under specially dry or wet conditions, 
Table 1. Winter temperature, salinity, dissolved oxygen and $p H$ values of Melides lagoon water, measured at surface, at $1 \mathrm{~m}$ depth and close to bottom sediment of each sampled site (in bold)

\begin{tabular}{|c|c|c|c|c|c|}
\hline Site & Depth (m) & Temperature $\left({ }^{\circ} \mathrm{C}\right)$ & Salinity (\%o) & Dissolved oxygen $\left(\mathrm{mg}^{-1}\right)$ & $\mathrm{pH}$ \\
\hline \multirow[t]{3}{*}{1} & 0.00 & 9.50 & 3.40 & 11.70 & 8.74 \\
\hline & 1.00 & 9.40 & 3.40 & 11.50 & 8.65 \\
\hline & 1.80 & 9.50 & 3.40 & 11.70 & 8.63 \\
\hline \multirow[t]{4}{*}{2} & 0.00 & 10.50 & 3.20 & 13.50 & 8.85 \\
\hline & 1.00 & 10.50 & 3.20 & 12.70 & 8.82 \\
\hline & 2.00 & 10.40 & 3.20 & 12.80 & 8.56 \\
\hline & 3.50 & 15.00 & 18.30 & 0.16 & 7.24 \\
\hline \multirow[t]{3}{*}{3} & 0.00 & 10.20 & 3.20 & 11.30 & 8.50 \\
\hline & 1.00 & 10.20 & 3.20 & 11.19 & 8.44 \\
\hline & 1.60 & 10.20 & 3.20 & 11.00 & 8.41 \\
\hline \multirow[t]{4}{*}{5} & 0.00 & 10.50 & 3.20 & 11.90 & 8.70 \\
\hline & 1.00 & 10.40 & 3.20 & 11.70 & 8.57 \\
\hline & 2.00 & 10.30 & 3.20 & 11.30 & 8.49 \\
\hline & 2.50 & 11.90 & 12.10 & 2.21 & 7.31 \\
\hline \multirow[t]{4}{*}{6} & 0.00 & 10.50 & 3.10 & 11.70 & 8.51 \\
\hline & 1.00 & 10.50 & 3.10 & 11.70 & 8.53 \\
\hline & 2.00 & 10.50 & 3.20 & 11.70 & 8.48 \\
\hline & 2.75 & 13.50 & 15.10 & 0.28 & 7.20 \\
\hline \multirow[t]{4}{*}{7} & 0.00 & 10.60 & 3.00 & 11.91 & 8.30 \\
\hline & 1.00 & 10.40 & 3.10 & 11.10 & 8.38 \\
\hline & 2.00 & 10.50 & 3.30 & 11.40 & 8.49 \\
\hline & 2.30 & 12.20 & 8.50 & 3.50 & 7.59 \\
\hline \multirow[t]{4}{*}{8} & 0.00 & 10.70 & 3.00 & 12.40 & 8.66 \\
\hline & 1.00 & 10.70 & 3.00 & 12.10 & 8.63 \\
\hline & 2.00 & 10.60 & 3.50 & 11.50 & 8.56 \\
\hline & 2.60 & 14.00 & 13.50 & 0.33 & 7.29 \\
\hline \multirow[t]{4}{*}{9} & 0.00 & 10.80 & 2.90 & 12.10 & 8.53 \\
\hline & 1.00 & 10.80 & 2.90 & 12.06 & 8.54 \\
\hline & 2.00 & 10.80 & 2.90 & 11.90 & 8.52 \\
\hline & 2.40 & 11.80 & 8.20 & 4.70 & 7.75 \\
\hline \multirow[t]{4}{*}{10} & 0.00 & 10.90 & 3.00 & 12.40 & 8.62 \\
\hline & 1.00 & 10.90 & 3.00 & 12.10 & 8.57 \\
\hline & 2.00 & 10.80 & 3.00 & 11.90 & 8.55 \\
\hline & 3.50 & 16.10 & 19.70 & 0.14 & 7.33 \\
\hline \multirow[t]{4}{*}{11} & 0.00 & 11.50 & 2.80 & 13.00 & 8.86 \\
\hline & 1.00 & 11.50 & 2.80 & 12.80 & 8.73 \\
\hline & 2.00 & 11.30 & 3.50 & 10.04 & 8.53 \\
\hline & 2.15 & 11.60 & 4.10 & 7.80 & 8.25 \\
\hline \multirow[t]{4}{*}{12} & 0.00 & 10.10 & 3.10 & 11.60 & 8.55 \\
\hline & 1.00 & 10.10 & 3.10 & 11.40 & 8.50 \\
\hline & 2.00 & 10.10 & 3.30 & 11.40 & 8.51 \\
\hline & 2.45 & 10.80 & 7.50 & 5.80 & 7.82 \\
\hline
\end{tabular}

as recorded between 1973 and 1990 (ARH Tejo 2011; Bettencourt et al. 2003). For an average tide, the flux close to the Tejo mouth is around $40000 \mathrm{~m}^{3} \mathrm{~s}^{-1}$ during flood and $50000 \mathrm{~m}^{3} \mathrm{~s}^{-1}$ with ebb. The dynamic tidal effects are felt to a distance of $80 \mathrm{~km}$ upstream and the salt edges reach $50 \mathrm{~km}$ upstream with a flux of $300 \mathrm{~m}^{3} \mathrm{~s}^{-1}$.

Tejo's salt marshes develop from the lower to the upper estuary, along $50 \mathrm{~km}$, over an area of $18760000 \mathrm{~m}^{2}$ (Bettencourt et al. 2003). They are very important in the left shore of the outer estuary, particularly in Seixal bay (Fig. 1) which forms a protected area, similar to an open lagoon and where the Alfeite transect (ALF) is located, the only one with an abundant ostracod population which comprises C. torosa.

In Tejo estuary, three salt marshes were studied (Fig. 1): Trancão (TRA), Rosário (ROS) and Alfeite (ALF), but C. torosa was found only in the Alfeite one. TRA salt marsh is relatively small, essentially muddy, located on the left bank of the lower Trancão estuary, which like the Minho, Lima and Mira estuaries is morphologically elongate, subjected to strong tidal currents, which does not allow the survival of $C$. torosa. ROS salt marsh is characterized by a sandy/sandy-mud substrate and a high and rapidly variable morphology, with meandering channels and rapid formation/destruction of large zones of low marsh and tidal flat, which must prevent the permanent presence of $C$. torosa.

ALF salt marsh is extensive, gently dipping, with a long tidal flat, irregular low marsh and short high marsh (Figs 4 and 5); the sediment is mud in the tidal flat and lower part of the low marsh, sandy-mud upwards, particularly on the high marsh. The main physical parameters of the interstitial waters have a small variation range along the transect. For temperature and $\mathrm{pH}$ : the temperature remains between 14.1 and $16.6^{\circ} \mathrm{C}$ in winter and 20.4 and $21.7^{\circ} \mathrm{C}$ in summer and the $\mathrm{pH}$ between 6.44 and 8.02 in winter and 6.14 and 7.27 in summer. The salinity varies between 18.5 and 29.10 in winter and 29.7 and 35.3 in summer; the dissolved oxygen between 0.15 and $6.43 \mathrm{mg} \mathrm{l}^{-1}$ in winter and 0.08 and $2.18 \mathrm{mg}^{-1}$ in summer. In ALF transect (Figs 4 and 5) C. torosa is mainly represented by juvenile valves ( $>60 \%$ of $C$. torosa population in winter; $>75 \%$ in summer) along the tidal flat and the low marsh; it is more abundant during winter (total of 1303 individuals, from which 


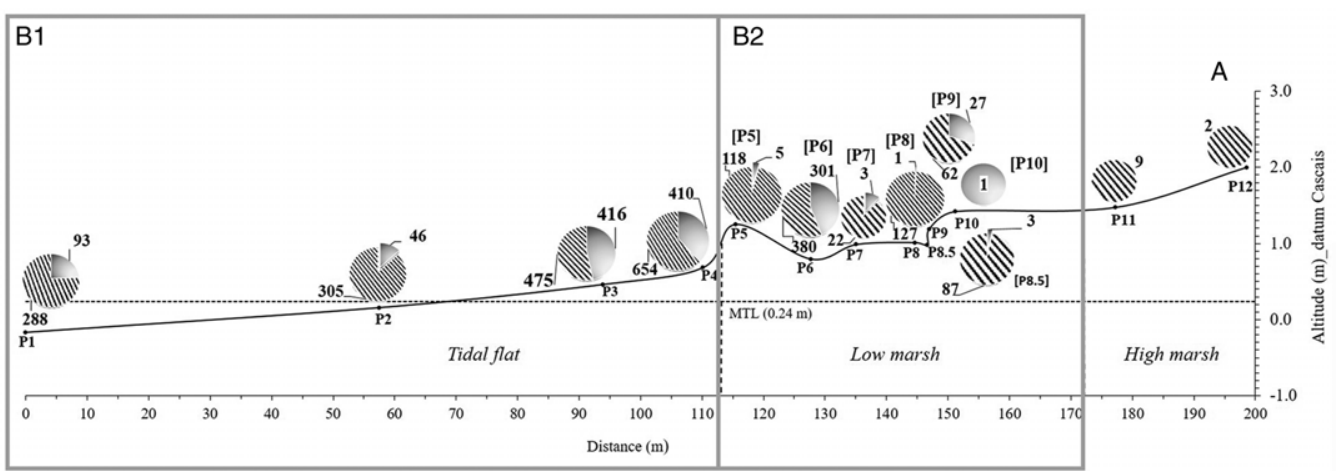

Cyprideis torosa NN Other species
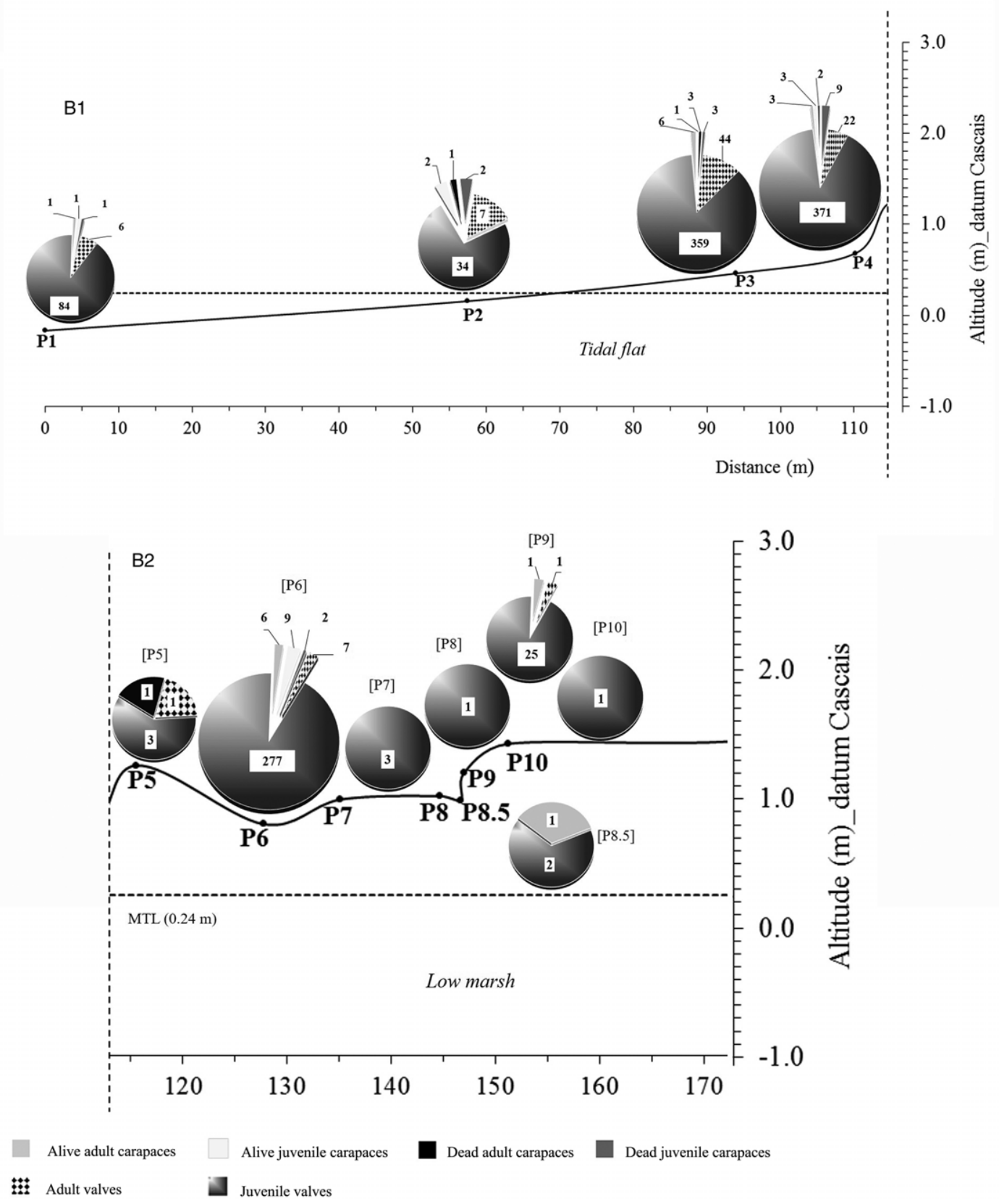

Fig. 4. Tejo estuary marsh transect ALF. (A) Distribution (\%) of Cyprideis torosa and other ostracod species along the transect in winter. (B1, B2) Distribution (\%) of Cyprideis torosa (carapaces, valves, adults, juveniles, dead, alive) along the transect in winter: (B1) along the tidal flat; (B2) along the low marsh. MTL, mean tidal level. Pie charts show number of individuals. Small pie chart: $<30$ individuals; medium pie chart: $30<$ individuals $<100$; large pie chart: $>100$ individuals.

34 were alive, compared to 502 in summer, from which 32 were alive); the live specimens are more abundant in the tidal flat, in winter and in summer, with adults better represented in winter. In the high marsh $C$. torosa was not found, the only species present being Terrestricythere cf. elisabethae Horne et al. and Tuberoloxoconcha cf. atlantica Horne, both in winter and 


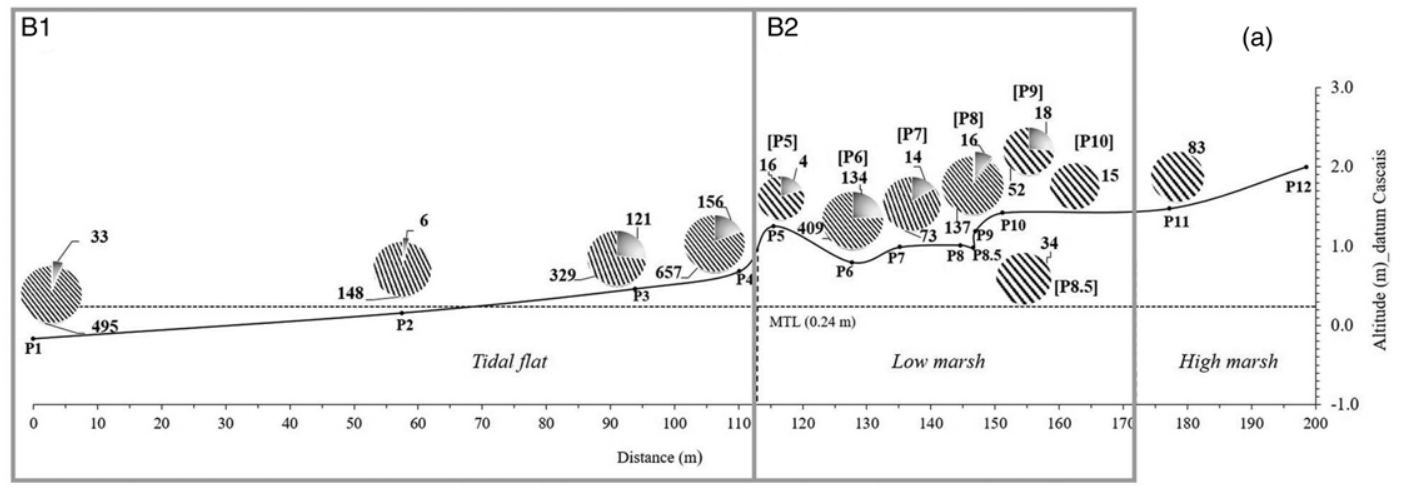

Cyprideis torosa N Other species

B1
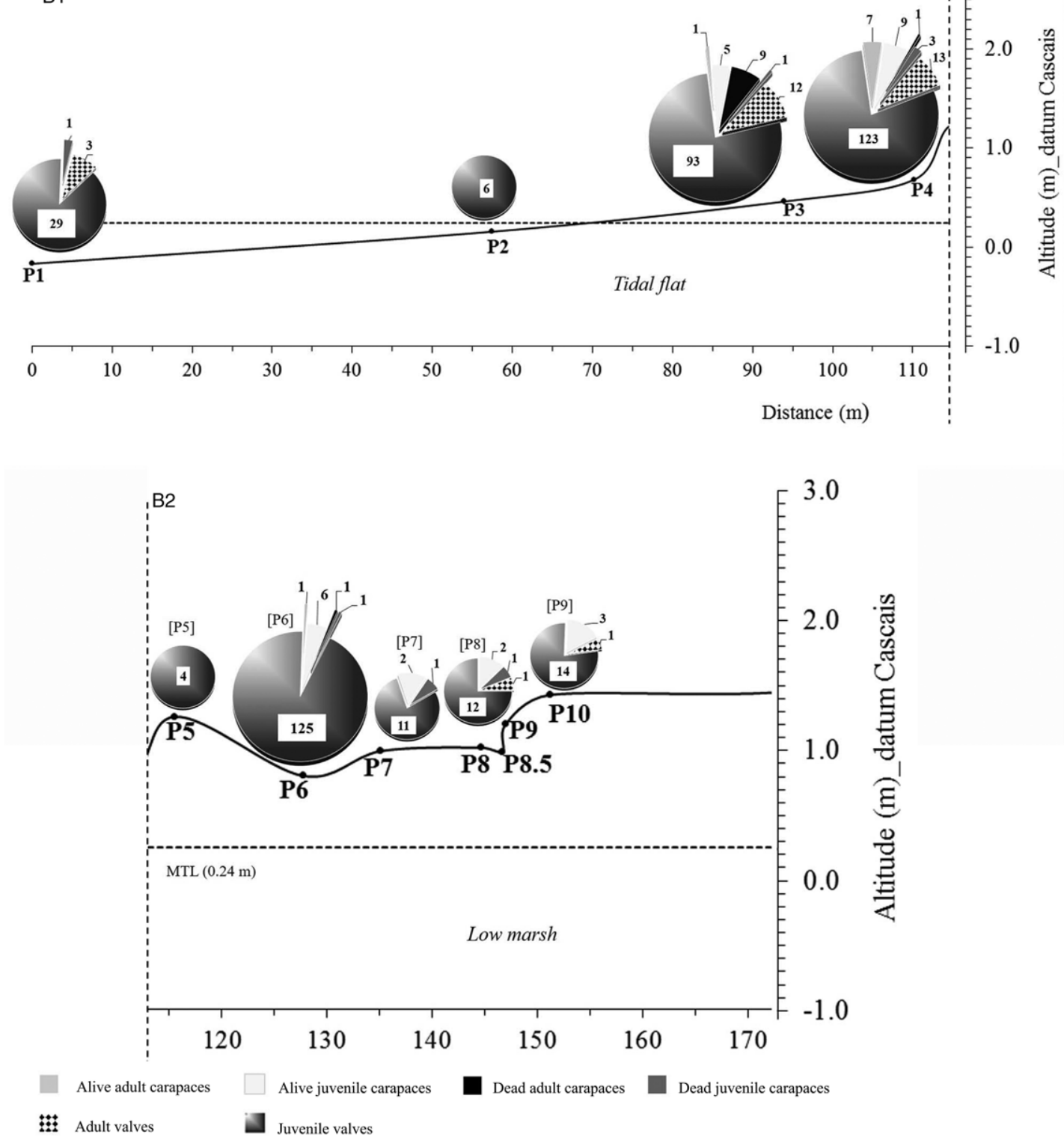

Fig. 5. Tejo estuary marsh transect ALF. (A) Distribution (\%) of Cyprideis torosa and other ostracod species along the transect in summer. (B1, B2) Distribution (\%) of Cyprideis torosa (carapaces, valves, adults, juveniles, dead, alive) in summer: (B1) along the tidal flat; (B2) along the low marsh. MTL, mean tidal level. Pie charts show number of individuals. Small pie chart: $<30$ individuals; medium pie chart: $30<$ individuals $<100$; large pie chart: $>100$ individuals.

summer. The diversity is low, with no more than 6 species per sample. Generally four brackish species, all of them autochthonous, with live individuals, are present in the tidal flat and the low marsh.
Ordered by abundance: Loxoconcha elliptica Brady, C. torosa, Leptocythere porcellanea (Brady) and Leptocythere lacertosa (Hirschmann), with L. elliptica largely dominant and mainly 


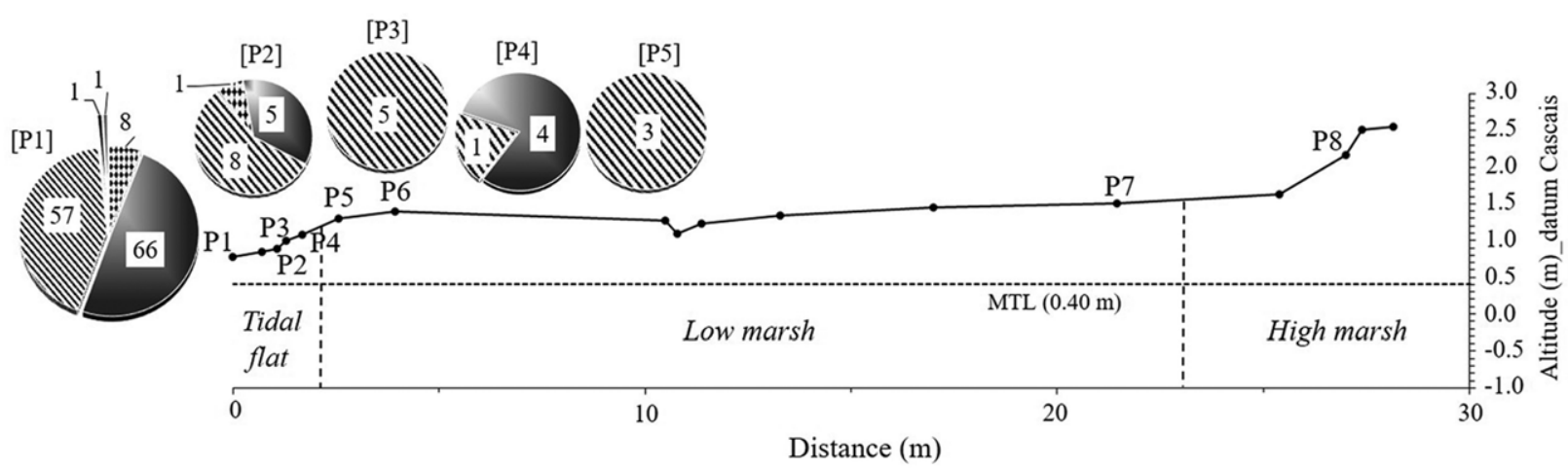

Dead adult carapaces

Dead juvenile carapaces

\$: Adult valves

Juvenile valves

NN Other species

Fig. 6. Sado estuary marsh transect CAR. Distribution (\%) of Cyprideis torosa (carapaces, valves, adults, juveniles, dead, alive) and other ostracod species along the transect in autumn. MTL, mean tidal level. Pie charts show number of individuals. Small pie chart: $<30$ individuals; medium pie chart: $30<$ individuals $<100$; large pie chart: $>100$ individuals.

represented, as C. torosa, by juvenile valves. Leptocythere porcellanea, though less abundant, has many live specimens, especially in the low marsh where it is the most important species. Leptocythere lacertosa is almost only present in the tidal flat. Cytherois fischeri (Sars) is rarely present in the tidal flat and Leptocythere ciliata Hartmann in the low marsh.

The Sado estuary is located on the SW coast of Portugal (Fig. 1). Its watershed defines an area of around $7670 \mathrm{~km}^{2}$. The average annual precipitation in the Sado basin is around $620-650 \mathrm{~mm}$ and its fluvial discharge varies from $1 \mathrm{~m}^{3} \mathrm{~s}^{-1}$ in the dry season to $50-80 \mathrm{~m}^{3} / \mathrm{s}$ under wet conditions, where peaks of $470 \mathrm{~m}^{3} \mathrm{~s}^{-1}$ may be recorded (Bettencourt et al. 2003). Sado's yearly average natural fluvial discharge is around $40 \mathrm{~m}^{3} \mathrm{~s}^{-1}$, very close to a Mediterranean type, but circulation inside the estuary is absolutely controlled by tides (Âmbar et al. 1980; Bettencourt et al. 2003). Considering a freshwater flux of $5 \mathrm{~m}^{3} \mathrm{~s}^{-1}$, a salt wedge penetrates $8 \mathrm{~km}$ upstream from Alcácer do Sal (Fig. 1), whereas tidal influence may be felt up to $15 \mathrm{~km}$ upstream from this town, around $60 \mathrm{~km}$ from the Sado mouth (Bettencourt et al. 2003).

The Sado estuary may be divided into two zones, the Alcácer channel ( 1 transect-ALC) and a wide basin, between its end and the mouth of the river, which has the behaviour of a coastal lagoon (Bettencourt et al. 2003). Sado's salt marshes are well developed along the widest basin ( 3 transects - CAR, FAR and TRO) and in both terminal banks of the Alcácer channel. All the studied transects are narrow and ostracods are poorly represented.

Cyprideis torosa is absent from ALC transect (Fig. 1), where the river is relatively narrow, with a strong flow, low salinity (c. 2.9 in autumn high-tide; c. 0.3 in spring low-tide) and marshes almost absent, short, muddy and only vegetated by Juncus. In the salt marshes of the widest basin (lower estuary) C. torosa is generally represented by few live forms on the tidal flat and low marsh.

CAR salt marsh is located in the left shore of Sado estuary (Fig. 1); it is c. $28 \mathrm{~m}$ in length (Figs 6 and 7). The sediment is mud to sandy-mud (Moreira et al. 2009). The main physical parameters of the interstitial waters have a small variation range along the transect. For temperature and $\mathrm{pH}$ : the temperature stays between 13.4 and $14.4^{\circ} \mathrm{C}$ in autumn and 15.8 and $17.1^{\circ} \mathrm{C}$ in spring and the $\mathrm{pH}$ between 6.83 and 7.02 in autumn and 6.85 and 7.10 in spring. The salinity varies between 26.2 and 43.3 in autumn and 30.9 and 41.7 in spring; the dissolved oxygen between 0.24 and $5.53 \mathrm{mg}^{-1}$ in autumn and 0.40 and $2.95 \mathrm{mg} \mathrm{l}^{-1}$ in spring. In the CAR transect (Figs 6 and 7) C. torosa is always dead, in autumn and in spring, mainly represented by juvenile valves in the tidal flat. It is the dominant species (c. $65 \%$ of the population in autumn; c. $60 \%$ in spring), followed, in autumn, by L. elliptica, L. porcellanea,

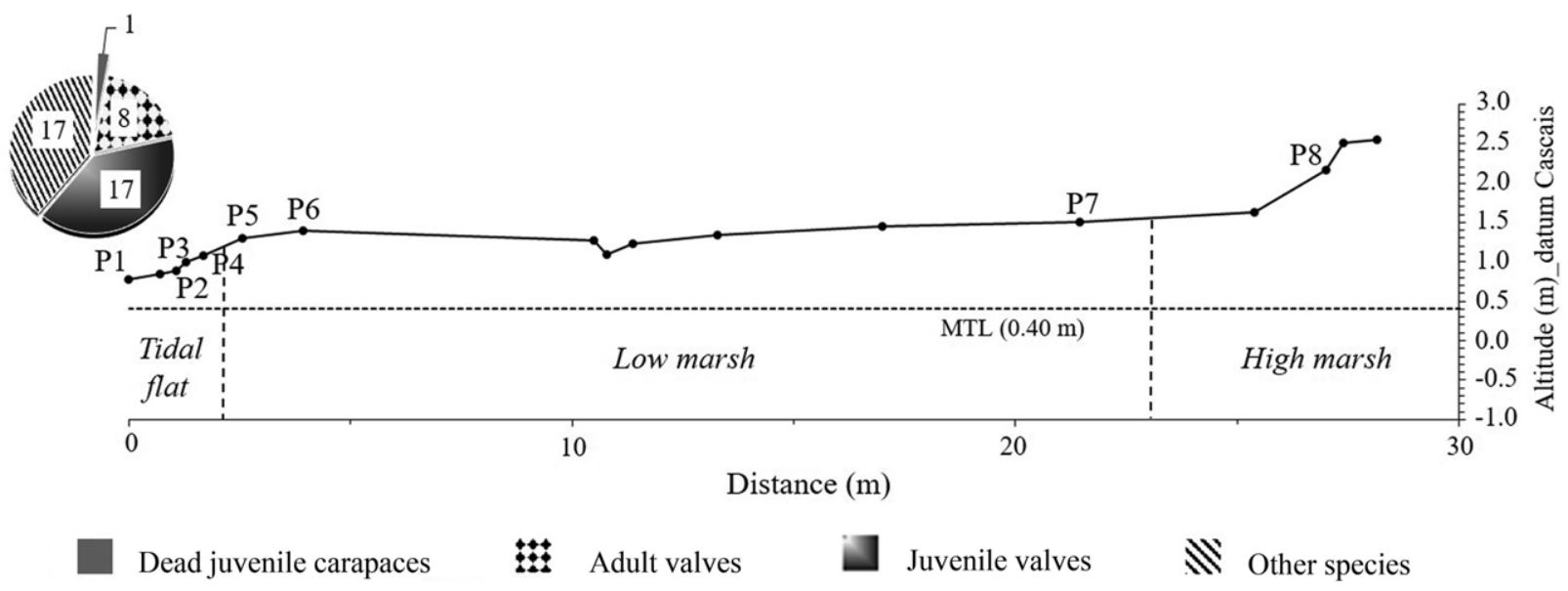

Fig. 7. Sado estuary marsh transect CAR. Distribution (\%) of Cyprideis torosa (carapaces, valves, adults, juveniles, dead, alive) and other ostracod species along the transect in spring. MTL, mean tidal level. Pie charts show number of individuals. Small pie chart: $<30$ individuals; medium pie chart: $30<$ individuals $<100$; large pie chart: $>100$ individuals. 


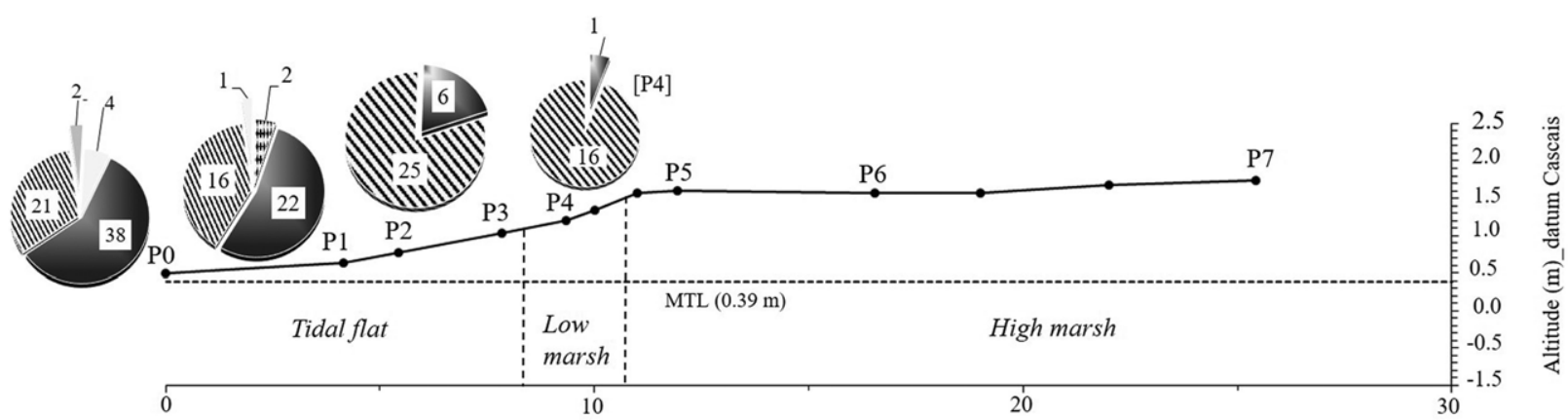

Distance (m)

Live adult carapaces

Live juvenile carapaces

\$: Adult valves

Juvenile valves

NN Other species

Fig. 8. Sado estuary marsh transect FAR. Distribution (\%) of Cyprideis torosa (carapaces, valves, adults, juveniles, dead, alive) and other ostracod species along the transect in autumn. MTL, mean tidal level. Pie charts show number of individuals. Small pie chart: $<30$ individuals; medium pie chart: $30<$ individuals $<100$; large pie chart: $>100$ individuals.

L. lacertosa, all with live and dead individuals and, finally, L. ciliata (1 live individual) and Callistocythere murrayi Whittaker (1 dead individual). In spring the ostracods were scarce, only represented in the lower part of the tidal flat (Fig. 7) by 3 species in addition to C. torosa: L. lacertosa (5 live, 4 dead individuals), L. elliptica (1 live, 1 dead individual) and L. porcellanea (1 dead individual). No ostracods were found on the high marsh, both in autumn and spring.

FAR salt marsh is located on the right shore of Sado estuary (Fig. 1); it is c. $25 \mathrm{~m}$ in length (Figs 8 and 9). The sediment is mud to muddy-sand (Moreira et al. 2009). The main physical parameters of the interstitial waters have a small variation range along the transect. For temperature and $\mathrm{pH}$ : the temperature remains between 12.1 and $13.3^{\circ} \mathrm{C}$ in autumn and 16.6 and $19.0^{\circ} \mathrm{C}$ in spring and the $\mathrm{pH}$ between 5.90 and 7.54 in autumn and 6.90 and 7.55 in spring. The salinity varies between 30.1 and 34.7 in autumn and 30.9 and 33.6 in spring; the dissolved oxygen between 0.28 and $6.12 \mathrm{mg}^{-1}$ in autumn and 1.69 and $3.10 \mathrm{mg} \mathrm{l}^{-1}$ in spring. In the FAR transect (Figs 8 and 9) C. torosa is present in the tidal flat, more abundantly in autumn (76 specimens) than in spring (35 specimens). It is represented almost only by juvenile valves and it is the dominant species in the lower part of the tidal flat, where live individuals were found: 7 in autumn and 1 in spring. In the low marsh one juvenile valve was found both in autumn and spring, together with a few specimens of $L$. ciliata (some alive in autumn and spring) and $L$. porcellanea (rarely alive in autumn); in the high marsh C. torosa is absent, as are other species.

In the tidal flat the diversity is low: 6 different species in autumn, including $C$. torosa, 7 in spring, the most important ones being
L. elliptica, L. ciliata and L. porcellanea in autumn, with rare live individuals, and Loxoconcha malcomsoni Horne \& Robinson, Paradoxostoma sarniense Brady, L. porcellanea and L. ciliata in spring, also with live individuals. It is important to stress the presence, in the tidal flat, of some worn valves belonging to sublittoral marine species, such as Urocythereis britannica Athersuch and Paracytheridea depressa G. W. Müller, which show the influence of tidal currents in this zone of the estuary.

TRO salt marsh is located in the left shore of the Sado estuary (Fig. 1), in a long south-north sand bar; it is c. $27 \mathrm{~m}$ in length (Figs 10 and 11). The sediment is mainly mud to muddy-sand in the tidal flat and low marsh, sand in the high marsh (Moreira et al. 2009). The main physical parameters of the interstitial waters have a small variation range along the transect. For temperature and $\mathrm{pH}$ : the temperature stays between 13.4 and $14.2^{\circ} \mathrm{C}$ in autumn and 15.9 and $20.5^{\circ} \mathrm{C}$ in spring and the $\mathrm{pH}$ between 6.39 and 7.15 in autumn and 6.29 and 7.53 in spring. The salinity varies between 16.2 and 32.2 in autumn and 17.1 and 34.1 in spring; the dissolved oxygen between 1.17 and $4.61 \mathrm{mg} \mathrm{l}^{-1}$ in autumn and 0.36 and $2.74 \mathrm{mg} \mathrm{l}^{-1}$ in spring. In TRO transect (Figs 10 and 11) C. torosa is mainly represented in the lower part of the tidal flat, in autumn and spring, by juvenile valves but also by live individuals (juveniles and adults): 9 in autumn, 7 in spring. In the lower part of the low marsh one juvenile valve was found in autumn, together with rare L. ciliata and C. fischeri; upwards, another juvenile valve was found in autumn, together with relatively abundant and live specimens of $L$. ciliata and $T$. cf. elisabethae; in the high marsh C. torosa is absent, as are other species. In the tidal flat the diversity is moderate: 9 different

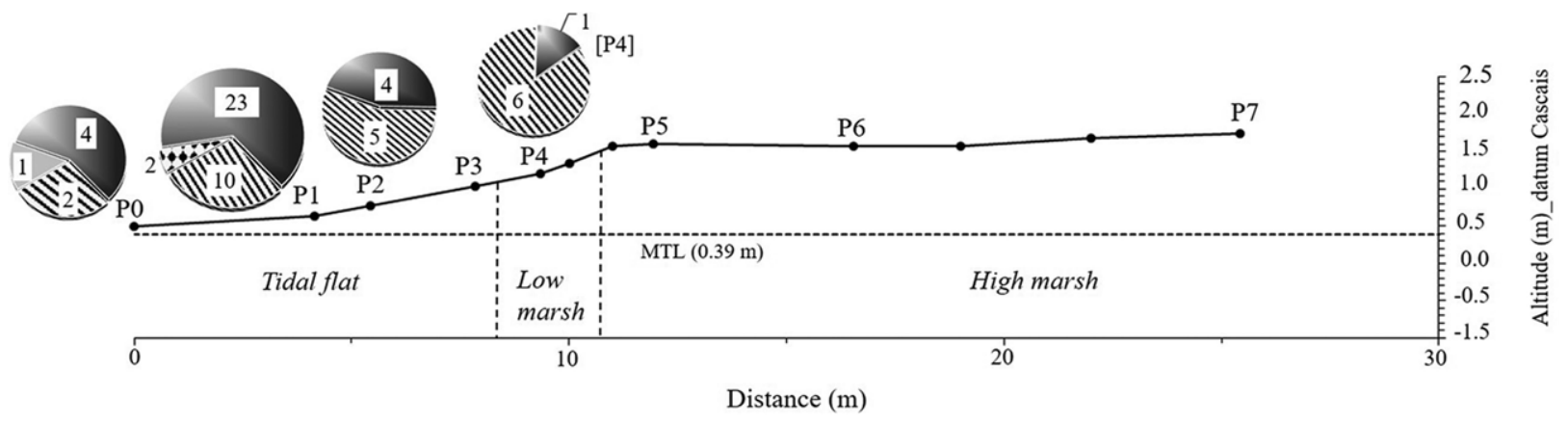

Live adult carapaces 苂 Adult valves Juvenile valves $\mathbf{N}$ Other species

Fig. 9. Sado estuary marsh transect FAR. Distribution (\%) of Cyprideis torosa (carapaces, valves, adults, juveniles, dead, alive) and other ostracod species along the transect in spring. MTL, mean tidal level. Pie charts show number of individuals. Small pie chart: $<30$ individuals; medium pie chart: $30<$ individuals $<100$; large pie chart: $>100$ individuals. 


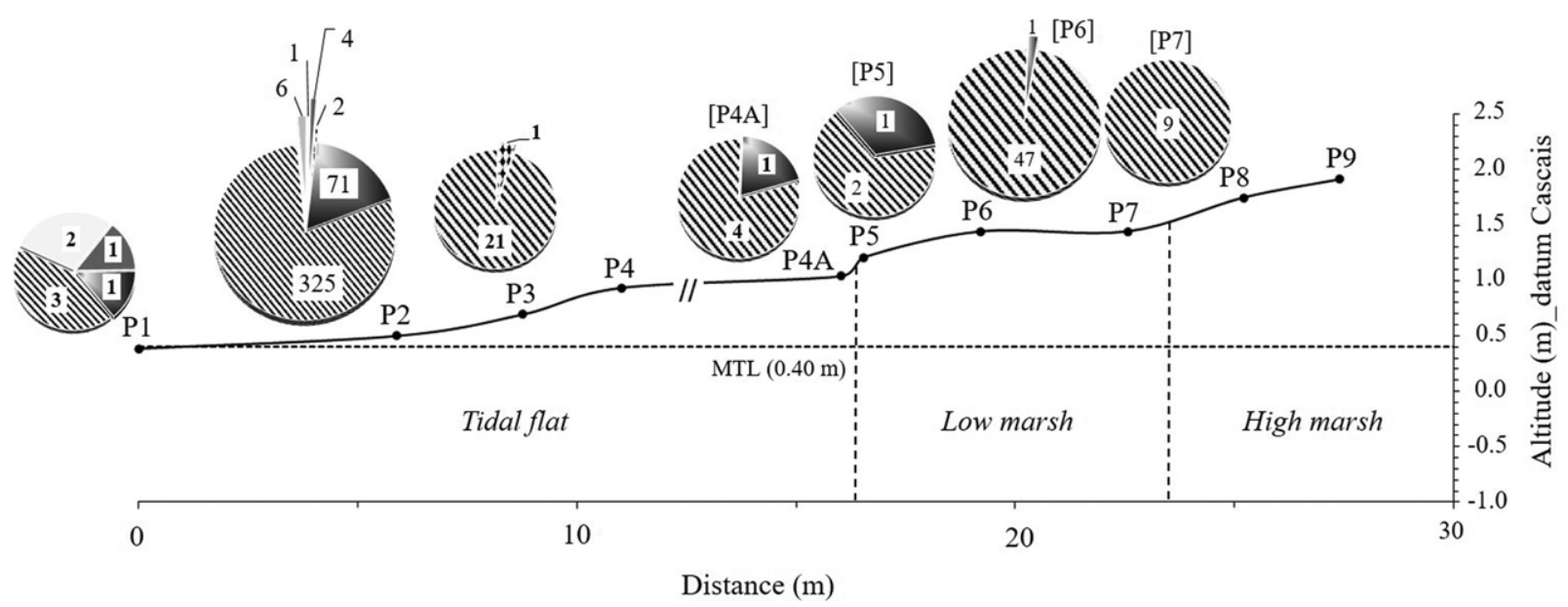

Live adult carapaces

Juvenile valves

\section{Live juvenile carapaces}

NN Other species
Dead juvenile carapaces

茫 Adult valves

Fig. 10. Sado estuary marsh transect TRO. Distribution (\%) of Cyprideis torosa (carapaces, valves, adults, juveniles, dead, alive) and other ostracod species along the transect in autumn. MTL, mean tidal level. Pie charts show number of individuals. Small pie chart: $<30$ individuals; medium pie chart: $30<$ individuals $<100$; large pie chart: $>100$ individuals.

species in autumn and spring, including C. torosa, the most important being $C$. fischeri ( $>100$ individuals in each season, with c. $50 \%$ alive), L. lacertosa and L. elliptica; the other species are: L. ciliata, L. porcellanea, Leptocythere sp. B, P. sarniense and L. malcomsoni (only dead) in autumn, and L. porcellanea, L. sp. B, P. sarniense, Paradoxostoma trieri Horne \& Whittaker and Semicytherura tela Horne \& Whittaker in spring.

In the Portuguese estuaries $C$. torosa is relatively abundant, but occurs alive only in the tidal flat and low marshes of sheltered areas, with low dynamics, as in lagoons, allowing deposition of soft mud to sandy mud substrates; in sandy substrates $C$. torosa never appears alive (only empty valves), thus showing a clear preference for finegrained sediments. In fact, in the studied transects $C$. torosa is much more abundant in ALF transect (Tejo estuary), which is the longest one, more sheltered, morphologically stable and muddy, located in a very quiet area. The total absence of $C$. torosa from the high marsh and its higher abundance in the tidal flat shows that it cannot survive long emersion periods.

The interstitial waters of the sediments where $C$. torosa lives are polyhaline to euhaline (salinity range 19.0-34.1), slightly alkaline ( $\mathrm{pH}$ range 7.06-8.02), with temperatures varying between 13.3 and $16.6^{\circ} \mathrm{C}$ in autumn/winter and 17.6 and $21.7^{\circ} \mathrm{C}$ in spring/summer and dissolved oxygen between $0.09-6.43 \mathrm{mg} \mathrm{l}^{-1}$. Along all the studied transects where $C$. torosa was found alive the maximum variation of these parameters was very close to the ones recorded for C. torosa in general (dead and alive). Major differences are related to $\mathrm{pH}$, which reaches values lower than 7 in all transects, both in Tejo and Sado estuaries, in autumn/winter and spring/summer. It is possible that the $\mathrm{pH}$ could control the distribution of $C$. torosa, since in all the samples where it was lower $C$. toros $a$ was not found alive.

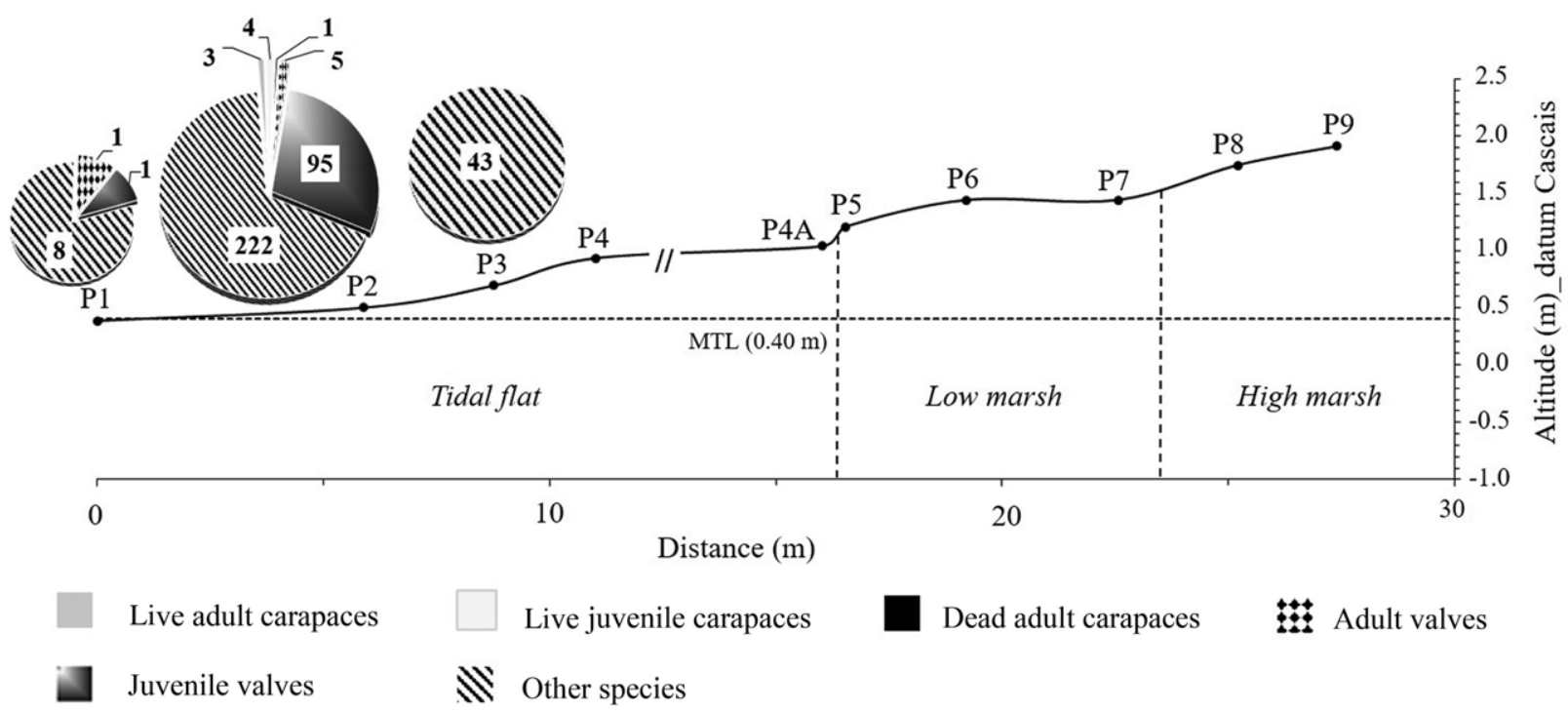

Fig. 11. Sado estuary marsh transect TRO. Distribution (\%) of Cyprideis torosa (carapaces, valves, adults, juveniles, dead, alive) and other ostracod species along the transect in spring. MTL, mean tidal level. Pie charts show number of individuals. Small pie chart: $<30$ individuals; medium pie chart: $30<$ individuals $<100$; large pie chart: $>100$ individuals. 


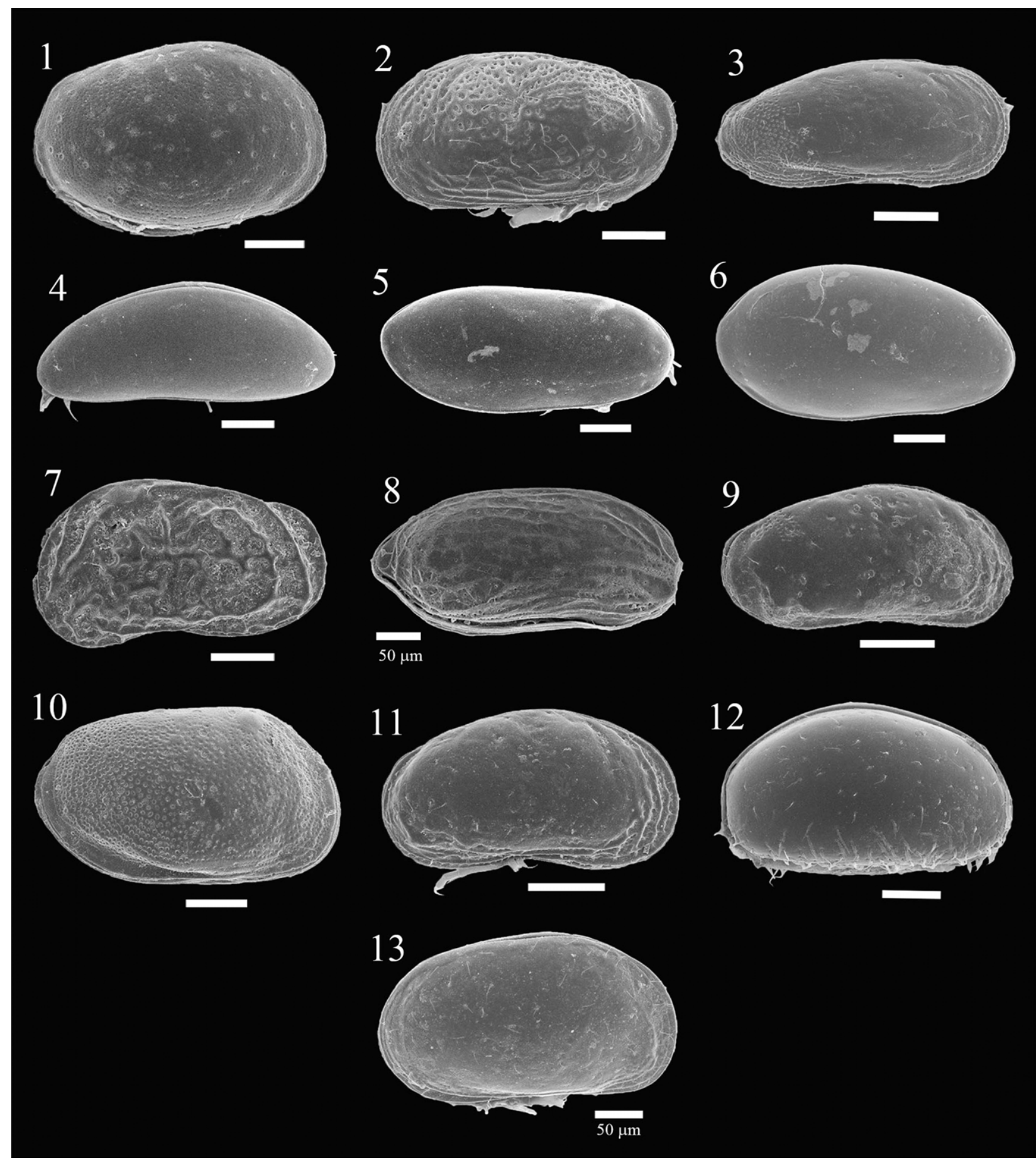

Fig. 12. Ostracod species found in Portuguese estuaries together with Cyprideis torosa. 1. Loxoconcha elliptica Brady, C, right view, f; Sado estuary, CAR-P1 aut.. 2. Leptocythere lacertosa (Hirschmann), C, left view, f; Sado estuary, TRO-P2 aut.. 3. Leptocythere porcellanea (Brady), C, right view, m; Sado estuary, TRO-P2 aut.. 4. Cytherois fischeri (Sars), C, right view, f; Sado estuary, TRO-P2 aut.. 5. Paradoxostoma sarniense Brady, C, right view, m?; Sado estuary, TRO-P2 aut.. 6. Paradoxostoma trieri Horne \& Whittaker, C, right view, f; Sado estuary, TRO-P2 spr.. 7. Callistocythere murrayi Whittaker, C, left view, f; Sado estuary, CAR-P1 aut.. 8. Semicytherura tela Horne \& Whittaker, C, right view, m; Sado estuary, TRO-P2 spr.. 9. Leptocythere sp. B, $\mathrm{C}$, right view, f; Sado estuary, TRO-P2 aut.. 10. Loxoconcha malcomsoni Horne \& Robinson, C, right view, f; Sado estuary, TRO-P2 aut.. 11. Leptocythere ciliata (Hartmann), C, right view, f; Sado estuary, TRO-P6 aut.. 12. Terrestricythere cf. elisabethae Horne, Smith, Whittaker \& Murray, C, right view, Sado estuary, TRO-P6 aut.. 13. Tuberoloxoconcha cf. atlantica Horne, C, right view, f?; Tejo estuary, ALF-P11 wint.. C, carapace; f, female; m, male; aut., autumn; spr., spring; wint., winter; scale bar $100 \mu \mathrm{m}$, except when indicated.

Cyprideis torosa tolerates hypoxic conditions, since it was found alive (though rarely) in sediments with interstitial water with a very low content of dissolved oxygen $\left(0.09 \mathrm{mg}^{-1}\right)$.

Cyprideis torosa is more abundant, with a more complete population represented mainly by adults and the last instars, during autumn/winter. According to Heip (1976) and Horne \& Boomer (2000) C. torosa has a life-cycle of one generation per year, with the main period of growth, maturation and reproduction in late spring and summer and the first adults appearing by autumn; the later-hatching individuals only mature in the following spring, leading to an overwintering population of larger juveniles and adults. The Portuguese population composition is in perfect accordance with these observations.

The ostracod assemblage, generally of low diversity, is composed of brackish species (Fig. 12), which vary in the tidal flat, low and 
high marshes according to their tolerance to the fluctuating environmental parameters, particularly substrate, emersion time, salinity and temperature. The most common species in the tidal flat, where diversity and abundance are higher, are $C$. torosa, $L$. elliptica, L. lacertosa, L. porcellanea and C. fischeri; more rarely, P. sarniense, P. trieri, L. malcomsoni and S. tela are also found. In the low marsh the most important species are L. ciliata, $L$. porcellanea, L. elliptica, C. torosa and T. cf. elisabethae (very rare) and, in the high marsh, only $T$. cf. elisabethae and $T$. cf. atlantica were found. The highest diversity was found in the tidal flat of the TRO transect, the most sandy and closest to the Sado estuary mouth; the higher diversity may be related to the different substrate, richer in sands, and to the higher dissolved oxygen content of interstitial waters.

\section{Melides lagoon}

The Melides lagoon encompasses a $0.4 \mathrm{~km}^{2}$ flooded area, its average depth and water storage capacity varying seasonally; the maximum depth does not exceed 5-6 $\mathrm{m}$ in the main channel where it abuts the southern bank (Fig. 2). The main lagoon body is separated from the open ocean by a closed sand barrier, consisting of a beach-foredune ridge and washover fans. The barrier is artificially breached at least once every year, generally in March/April, during spring tides, near site MEL 1; usually the inlet silts up naturally in less than one week. The physico-chemical parameters of the lagoon water mass are essentially controlled by the alternating opening/ closure of the inlet. When the inlet is open, semi-diurnal tides propagate into the lagoon, renewing and homogenizing the water mass. When the inlet is closed (autumn and winter) the lagoon collects freshwater from the Melides rivulet and watershed, increasing its depth and generating a stratified water mass (Freitas et al. 2002).
The measured physico-chemical parameters in February 2015 are typical of a closed-inlet situation and the hydrosome below $2 \mathrm{~m}$ depth showed a clear increase in temperature and salinity and decrease in $\mathrm{pH}$ and dissolved oxygen (Table 1). In contrast with the homogeneity of the surface water, the characteristics of the near bottom water are variable in space.

In Melides lagoon C. torosa is extremely abundant, sometimes so abundant that its valves constitute a component of the bottom sediment; it is the most abundant and most frequently occurring ostracod species and it is the dominant species in all samples (Fig. 13).

From a total of 10341 individuals, around 87\% (8984 individuals) are $C$. torosa. In general it is more heavily represented ( $>800$ individuals per sample) in the quiet north and central-eastern areas (sites 6, 8, 9, 11 and 12) than in the southern areas, where it may be absent (sites 1, 2 and 3 ) or vestigial (site 10); in site 5, though well represented, all the specimens were dead, including the other species. Site 7 is very particular since it is represented by a mono-specific population of $C$. torosa, with a high number of live individuals (93 in a total of 522), only exceeded in sample 11, but proportionally lower (195/2248).

Cyprideis torosa is particularly represented by valves, many in hyaline condition and belonging to all juvenile stages (generally $>50 \%$ of the individuals in each sample); the adult valves, also mainly hyaline, represent $<1 / 3$ of the juvenile valves in each sample (Fig. 13); the number of dead and juvenile carapaces generally exceeds the number of live and adult ones; the live individuals are only present in the northern and central-eastern area of the lagoon (sites 6, 7, 8,9,11 and 12), suggesting the preference of the species for quiet zones, far from the main channel of the lagoon (Fig. 2), where deposition of fine sediments is promoted. In fact, the samples of these sites correspond to mud and muddy sand, containing more

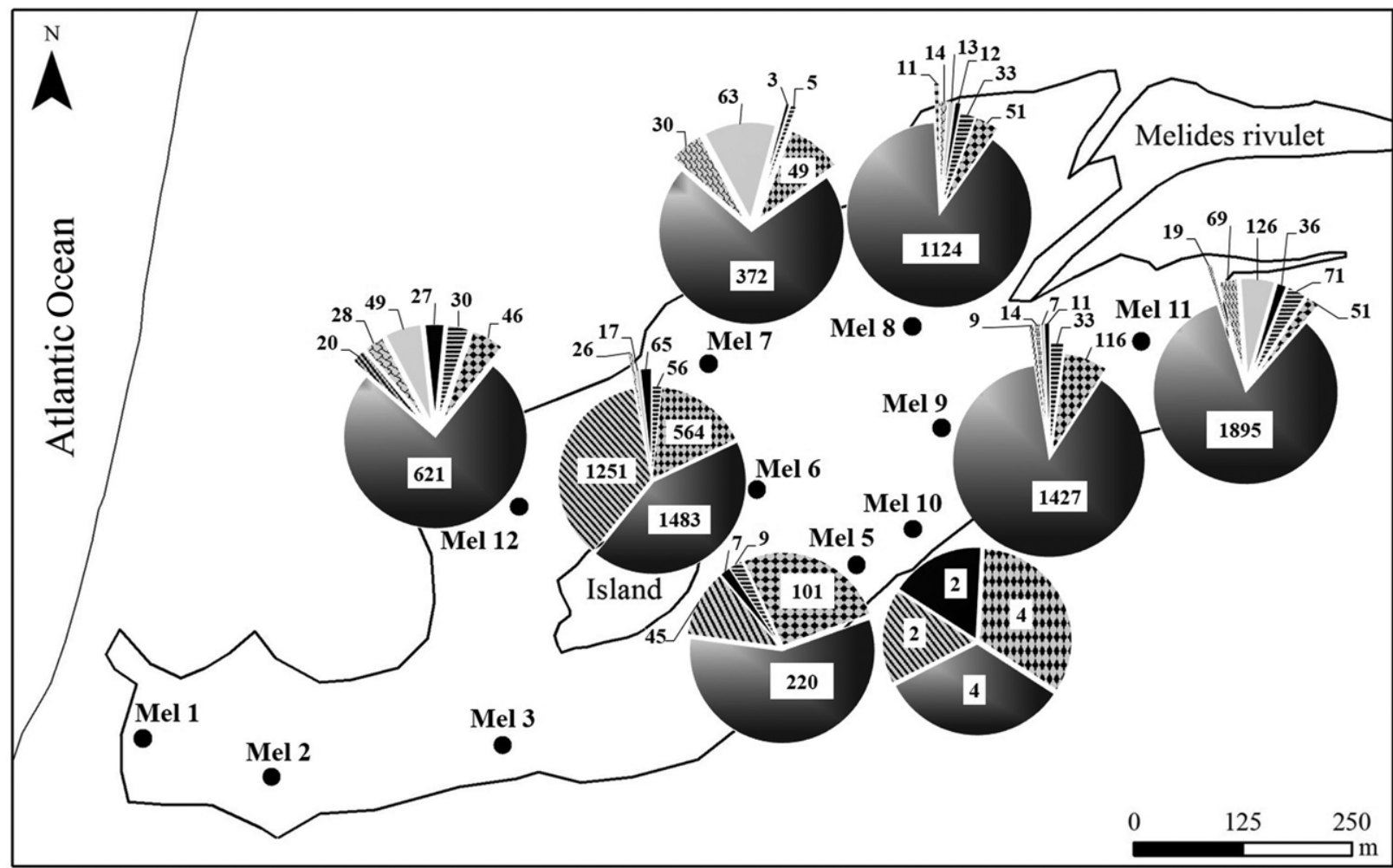

Live adult carapaces

Live juveline carapaces

Dead adult carapaces

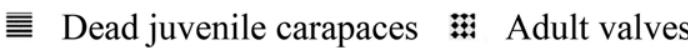

i. Juvenile valves

$\mathbb{N}$ Other species

Fig. 13. Distribution (\%) of Cyprideis torosa (carapaces, valves, adults, juveniles, dead, alive) and other ostracod species in Melides lagoon in winter. Pie charts show number of individuals. 


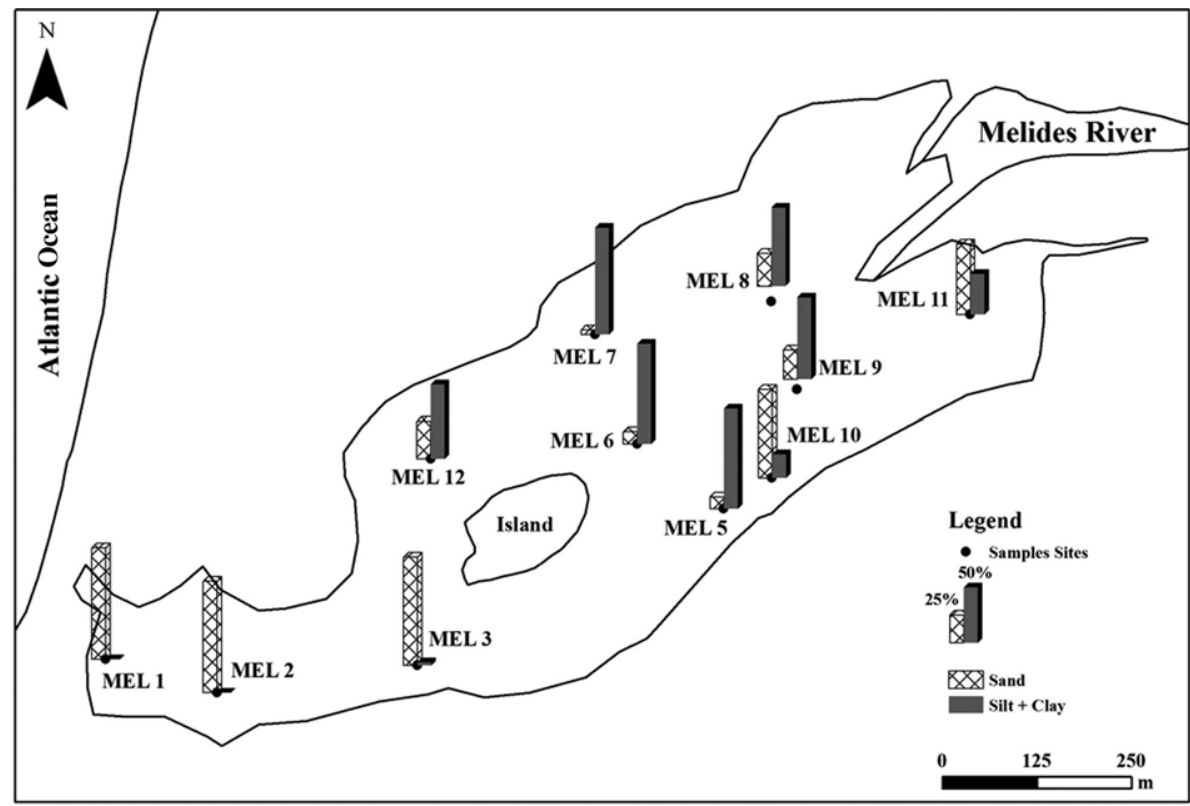

Fig. 14. Sand and silt + clay contents of the bottom sediments of Melides lagoon.

than $66 \%$ of silt + clay, except in site 11 (only $36.7 \%$ of silt + clay; Fig. 14); however, the latter site presents a high value of dissolved oxygen $\left(7.8 \mathrm{mg}^{-1}\right.$; Table 1$)$, which can possibly explain the abundance of live C. torosa; in site 7, where the live forms are also abundant, the sediment is muddy, with $96 \%$ of fine material.

The diversity is very low. Cyprideis torosa is always dominant and generally there are no more than 4 species per sample. The highest species diversity is found in sample 6 , with at least 7 species, the most abundant being brackish forms (C. torosa and Loxoconcha elliptica); the remaining freshwater ones, all of them tolerating low salinities (Meisch 2000) are: Cypria cf. subsalsa Redeke, Heterocypris salina (Brady), Cypridopsis vidua (O.F. Müller), Sarscypridopsis aculeata (Costa) and Ind. Gen. sp. (unidentified juveniles) (Fig. 15). Most of the freshwater species are represented by allochthonous juvenile valves of Ind. Gen. sp., possibly transported from the nearby island (Fig. 13). The low salinity values in the bottom of the water mass, varying from 3.2 to 19.7 (with live ostracods being present only in sites with a salinity range between 4.1 and 15.1) explains the observed low ostracod diversity and the complete absence of marine species. Cyprideis torosa prefers oligo- to mesohaline waters, the living forms being more abundant in sites 7 and 11 (salinity $=8.5$ and 4.1 , respectively).

In summary, C. torosa is the main ostracod found in Melides lagoon and the only live species found during the winter season. Most of the population is autochthonous, but the presence of many worn or opaque valves in some sites, and the rare presence of some

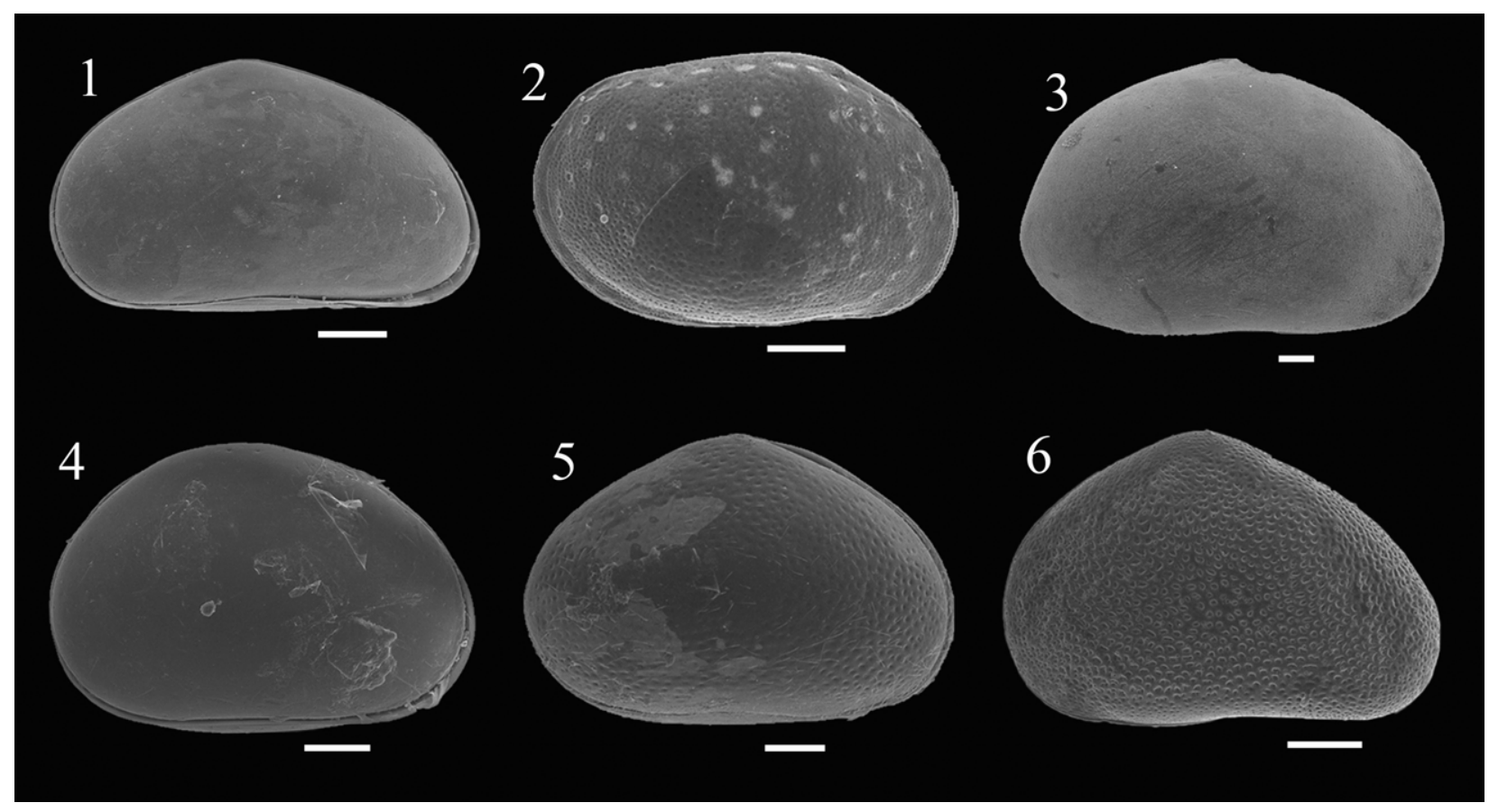

Fig. 15. Ostracod species found in Melides lagoon, together with Cyprideis torosa. 1. Ind. Gen. sp., C, left view, j; MEL6 wint.. 2. Loxoconcha elliptica Brady, RV, external, f; MEL12 wint.. 3. Heterocypris salina (Brady), RV, external; MEL6 wint.. 4. Cypria cf. subsalsa Redeke, C, right view, MEL6 wint. 5. Cypridopsis vidua (O.F. Müller), C, right view, f; MEL6 wint.. 6. Sarscypridopsis aculeata (Costa), LV, j; MEL6 wint.. C, carapace; LV, left valve; RV, right valve; f, female; j, juvenile; wint., winter; scale bar $100 \mu \mathrm{m}$. 
'freshwater' species in almost all samples, suggests remobilization inside the lagoon. Cyprideis torosa prefers to live in a soft mud to muddy sand substrate, in quiet oligo- to mesohaline waters, with a range of dissolved oxygen from 0.28 to $7.8 \mathrm{mg} \mathrm{l}^{-1}$ and $\mathrm{pH}$ from 7.20 to 8.25. Due to its exceptional abundance in some of the Melides samples and in other Portuguese lagoons (Santo André and Albufeira, unpublished data) it is evident that the lagoonal environment is one of its preferred habitats.

\section{Palaeontology research}

\section{Holocene}

In the studied sedimentary columns from Holocene marginalmarine environments, all of them dated using $\mathrm{AMS}{ }^{14} \mathrm{C}$ radiocarbon dating techniques on particulate carbon in sediment (dates undertaken by Beta Analytic Radiocarbon Dating Laboratory, Miami, USA), C. torosa is always present, its vertical (in time) distribution depending on the marine influence and river discharge. An evolutionary model for the Holocene of western Iberian marginalmarine environments has already been established; this model considers drowning of previously dissected landscapes by the Holocene transgression, followed by barrier encroachment contemporaneous with deceleration of sea-level rise in the middle Holocene. Early estuarine/ria environments were transformed into lagoons and barred estuaries, the former permanently or temporarily closed by sandy barriers (e.g. Santo André, Melides, Pederneira and Sizandro lowlands, Fig. 3; Cearreta et al. 2003; Freitas et al. 2003; Cabral et al. 2006, 2011; Lord et al. 2011). One paradigmatic example is illustrated in Figure 16, from Pederneira estuary/lagoon (borehole S2), near Nazaré.

In all lowlands several palaeoenvironmental stages may be recognized, with the earliest (Lateglacial to Early Holocene; Fig. 16, Zone I) and the latest (Late Holocene; Fig. 16, Zone V) being characterized by total or almost total absence of ostracods. In the first (oldest) stage this absence is interpreted as due to a high energy fluvial environment, contemporaneous with a sea level much lower than the present one. In the last (youngest) stage the absence of ostracods is interpreted as due to the terrestrialization of the former barred marginal-marine systems by progressive infilling with fluvial sediments; when ostracods are present, they are very rare, belonging to freshwater genera such as Ilyocypris, Heterocypris and Limnocythere, all of them with species tolerating slightly salty inland and coastal waters (Meisch 2000). In between these two stages, two to five more can occur (some including substages), their number depending on the physical characteristics of the marginal-marine system and on the location of the borehole (alluvial plain, barrier, medium estuary, lagoon, etc.).

The second stage (Early Holocene; Fig. 16, Zone II) records the first occurrence of ostracods, initially represented by brackish forms, generally C. torosa and Loxoconcha elliptica, both scarce and mixed with a few littoral marine forms also in low abundance; C. torosa is usually represented by empty valves, some hyaline, some opaque, some worn. This stage corresponds to a progressive development of a brackish estuarine environment, due to the rapid sea-level rise during the Holocene transgression.

In the third stage (Middle Holocene; Fig. 16, sub-zones IIIA and IIIB) C. torosa (and L. elliptica) are usually (but not always) present, varying in number; $C$. torosa is represented by adult and juvenile carapaces and valves, both hyaline and opaque, sometimes worn, with a mixture of autochthonous and allochthonous faunas. However, the littoral and sub-littoral marine species are the most diverse and abundant forms and progressively increase upstage, generally reaching their maximum (c. 10-60 different species) at the top; in some cases, deep-water marine species are also found. This stage developed in consequence of rapid sea-level rise promoting the progressive change of the former incipient estuarine environment into a deeper, fully or almost fully marine one, with salinity near 30-35.

Finally, in the fourth stage (Middle and Late Holocene; Fig. 16, Zone IV) almost only brackish species are present; $C$. torosa is, in general, abundantly represented, frequently by hundreds of valves and carapaces, most of them hyaline and well preserved, forming mono- to oligo-specific autochthonous assemblages; in the latter case, C. torosa is accompanied by L. elliptica, which varies significantly in abundance. The existence of nearby salt marshes is indicated by scarce Cytherois fischeri and species of the genus Leptocythere, among which $L$. porcellanea and L. lacertosa are the most important. In addition, rare freshwater species, represented only by one or two specimens have also been found. This stage is contemporaneous with a pronounced decrease in the rate of sea-level rise followed by stabilization of mean sea level close to the present-day level; in most cases it corresponds to the development of a restricted lagoonal environment, separated from the sea by a very effective sandy barrier.

The similarity in abundance, dominance, population composition and preservation of C. torosa found in present-day lagoons, such as Melides, and in the Holocene sedimentary record, demonstrates the utility of this ostracod species as a marker to interpret lagoonal environments developed during the Holocene.

In cases where marginal-marine environments remained throughout the Holocene as open estuaries with intense flow, C. torosa is poorly represented in sediment (e.g. Schriek et al. 2008, on the Tejo upper estuary). Results obtained by Almeida et al. (2009) from the PC core made in the Tejo estuary (Fig. 3) are congruent with this observation. Here, the hydrodynamic regime allowed $C$. torosa to be represented by only rare worn valves, in 2 samples out of 100 studied. These samples yielded high ostracod diversity, with autochthonous and allochthonous assemblages, C. torosa clearly being a transported form.

In the Mira estuary (Fig. 1), a 27 m-long borehole (MIRA-CP1) drilled in the alluvial plain of the Corgo do Porto tributary, located $3.5 \mathrm{~km}$ upstream from the mouth, was studied for foraminifera by Alday et al. (2006). Cyprideis torosa was only found in the upper section of the core (between 1.94 and 3.99 m below mean sea level), in muddy and sandy substrate, together with other brackish species generally found in salt marshes and/or in open estuarine environments, e.g. C. fischeri, L. lacertosa, L. elliptica, L. malcomsoni, Leptocythere fabaeformis (G.W. Müller), Loxoconcha rhomboidea (Fischer), Xestoleberis labiata Brady \& Robertson; towards the base of this section of the core, littoral marine species were also well represented, such as Carinocythereis whitei (Baird), Aurila convexa (Baird), $U$. britannica (unpublished data, ongoing work). In terms of palaeoenvironmental reconstruction, these results are in agreement with those obtained from foraminifera (Alday et al. 2006); in fact, C. torosa occurs in foraminiferal zones dated to the Middle-Late Holocene that were interpreted by those authors as indicating the development of a progressively more restricted estuarine environment. This phase matches the time-window during which the lagoonal phase was established in the other studied Portuguese marginal-marine barred environments previously discussed. This suggests that $C$. torosa only occurred in the Mira estuary during a less energetic period, post-dating the stabilization of sea-level rise, and probably colonizing salt marshes.

Similar results were found by Hindson et al. (1999), Hilbich et al. (2008) and Trog et al. (2013, 2015) in several Holocene estuaries on the southern Portuguese coast. Cyprideis torosa occurs through the cores, usually associated with L. elliptica and other brackish and marginal-marine species. The assemblages vary according to the estuary (more open, more restricted), but for the time period characterized by progressive siltation related to the stabilization of sea-level rise, they are generally represented by the brackish species C. torosa, L. elliptica, Leptocythere spp. and Cytherois fischeri, together with a few littoral marine species. This is the case in Alcantarilha estuary (Trog et al. 2013), with C. torosa, L. elliptica, 


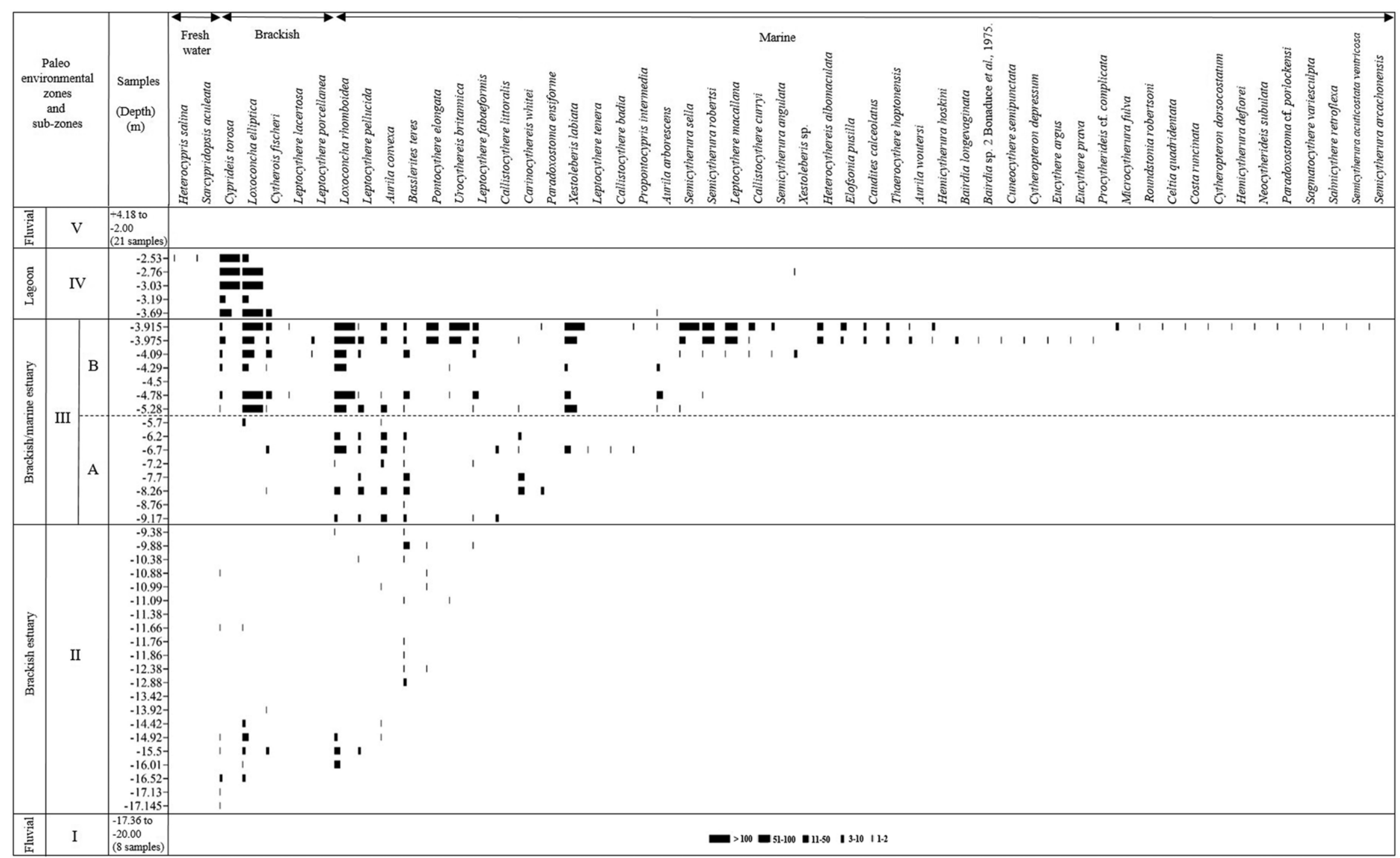

Fig. 16. Frequency distribution of the ostracod species in S2 borehole, Pederneira estuary/lagoon, Nazaré, along the Holocene, with indication of the palaeoenvironmental ostracod zones, abundance, diversity and ecological groups. Systematics list in Cabral \& Loureiro (2013). 
Leptocythere spp. and the marine species U. britannica and Cytheretta adriatica Ruggieri.

We conclude that the behaviour of $C$. torosa during the Holocene and in modern times was very similar, in analogous environments, the species being more abundant in lagoons than in estuarine tidal flats and salt marshes, preferring brackish waters, oligo- to polyhaline, relatively quiet, with muddy and sandy-mud sedimentation. This highlights the influence of these three parameters (salinity, water dynamics, substrate) in controlling the distribution of the species. Water dynamics and substrate vary less than the salinity, suggesting that salinity plays a weaker role.

\section{Miocene, Pliocene and Pleistocene}

There are few studies and publications about the brackish Miocene, Pliocene and Pleistocene Portuguese ostracods. Nascimento, who studied Miocene ostracod assemblages both in the Tagus Basin (Nascimento 1981) and in the Algarve (Antunes et al. 1981), never refers to the presence of $C$. torosa. Most of the ostracod species found were marine and very few were typical of freshwaters. In Nascimento (1993), dedicated to the Cyprideis group taxa occurring in the Tagus Basin, the species considered belong to the genera Hemicyprideis, Miocyprideis and Neocyprideis. For the Pliocene, ostracods have rarely been studied. Only Nascimento (1990) reported a Pliocene ostracod 'biozone' from an infralittoral environment, without $C$. torosa. Finally, in the Pleistocene, the published works concerning Portuguese ostracods, all focused in the Algarve region (Antunes et al. 1986; Cabral et al. 2004, 2005a, b), only reported freshwater to slightly brackish (oligohaline) species, not including C. torosa.

\section{Morphology of valves}

\section{Surface ornamentation - nodes, punctation, reticulation}

It is well known that the surface of $C$. torosa valves show wide variation, from smooth to punctate, reticulate, with or without nodes. This variation in surface features has been studied in several works (e.g. Sandberg 1964; Kilenyi 1972; Carbonel 1980; Bodergat et al. 1991; Gliozzi \& Mazzini 1998; Keyser 2005; Frenzel et al. 2012), and is usually related to the salinity range and water chemistry.

Nodes appear in low salinity (oligohaline) environments. Some authors quote a salinity critical level, but they give widely different values. Kilenyi (1972, p. 51) states that although noded specimen numbers increase with decreasing salinity, '... there is no linear or even simple nonlinear relationship between the two'. Keyser (2005) explains the appearance of nodes by pathological reactions during the moulting process, influenced by the total ion concentration and $\mathrm{Ca}^{2+}$ availability. Frenzel et al. (2012) conclude that there is a clear negative linear correlation between the proportion of noded individuals from the Baltic Sea coast and salinity, and that deficiency of $\mathrm{Ca}^{2+}$ causes heavier noding in laboratory cultures, the critical level, depending also on stability of salinity conditions, varying from 8 to 14 .

Salinity is also the parameter most invoked to explain differences in valve ornamentation. For Gliozzi \& Mazzini (1998), more reticulated shells are common at low salinities, whereas at higher salinities (above 10\%) the shells become either punctate or smooth. Carbonel (1980) studied the reticulation of C. torosa populations from different climatic regions and environments and concluded that valve reticulation does not depend on water salinity but is related to the $\mathrm{Mg}^{2+}$ content, particularly the $\mathrm{Mg}^{2+} / \mathrm{Ca}^{2+}$; when $\mathrm{Mg}^{2+}$ $/ \mathrm{Ca}^{2+}>3$, valves became reticulate; for $\mathrm{Mg}^{2+} / \mathrm{Ca}^{2+}<3$ valves are finely punctate or even smooth; on the contrary, noding seems directly related with salinity. Bodergat et al. (1991) relate the nodes, reticulation and heavy calcification of the carapaces to the presence of dissolved $\mathrm{Si}, \mathrm{Al}, \mathrm{Fe}, \mathrm{Mn}$ and $\mathrm{Ba}$ ions in the water.
In all the studied Portuguese material the valves of $C$. torosa, adults and juveniles, are generally well calcified, always without nodes, and their surfaces are smooth or almost smooth (Fig. 17:12), punctate (Fig. 17:1, 17:6, 17:8) or reticulate (Fig. 17:3), the punctate being the most frequent. The punctation pattern varies from fine to coarse pits and the reticulated valves are the rarest ones.

In the modern estuaries of Tejo and Sado the valves are generally finely punctate, but all types of ornamentation were found. In ALF transect (Tejo), most valves are finely punctate to smooth, the latter being most frequent in juveniles; there are no reticulated valves and the coarsely punctate valves are relatively rare. In the three Sado transects (CAR, FAR and TRO) the valves are also punctate, but generally more coarsely and, in some cases, reticulated, particularly in the adults from the lowest part of the tidal flat; juvenile valves are mainly finely punctate to smooth. The differences in ornamentation found in these two estuaries cannot be explained by salinity differences. The salinity measured in interstitial waters in Tejo (ALF) and Sado (FAR, CAR, TRO) is high: Tejo (19.0-34.3); Sado (26.2-41.4) and this should promote punctate or smooth valves, according to Gliozzi \& Mazzini (1998). This happens in Tejo estuary (ALF), but in Sado estuary (CAR, FAR and TRO), where the salinity is even higher, the valves are coarsely punctated, even reticulated (Fig. 17:1, 17:3, 17:6) in all transects. Following Carbonel (1980), the $\mathrm{Mg}^{2+} / \mathrm{Ca}^{2+}$ content of the water should be the main control of the $C$. torosa valve ornamentation. Unfortunately, no $\mathrm{Mg} / \mathrm{Ca}$ data are available to test this relationship in the areas addressed in this study.

In the modern material from Melides lagoon most valves are finely punctate, both juveniles and adults; several adult valves are nearly smooth and less frequently coarsely punctate, this last type being more abundant in males. However, two samples exhibit a variation in ornamentation: MEL 6, where most of the valves (juveniles, females and males) are slightly thinner, very finely punctate or almost smooth, the coarsely punctate being almost absent; MEL 11, with almost all the valves well calcified and punctate, the smooth ones absent. Curiously, these two samples correspond to the extreme values of salinity found in the lagoon (15.10 in MEL 6 and 4.10 in MEL 11), suggesting the existence of a relationship between ornamentation and salinity, ornamentation being more pronounced at low salinity, in agreement with Gliozzi \& Mazzini (1998).

In the Holocene material all types of ornamentation were found (punctate, smooth, reticulate) in the same sample, except in Pederneira lagoon, core S2 (Cabral et al. 2011), where we clearly observed an evolution in the valves of $C$. torosa belonging to the lagoonal environment (Fig. 16, Zone IV). In the base of Zone IV the valves of $C$. torosa were less ornamented (smooth or punctate) and in the top of the same zone they were more strongly punctate or reticulate, suggesting an alteration in water chemistry, probably a decrease in salinity, in agreement with the proposed evolution model.

The only known Portuguese noded specimens of $C$. torosa were found by Trog et al. (2015), in Central Algarve, south Portugal, in Holocene sediments from Carcavai estuary, together with no-node specimens of $C$. torosa and other brackish species, such as L. elliptica and C. fischeri.

From our observations in marginal-marine environments of mainland Portugal it was not possible to explain the variation in the ornamentation of $C$. torosa valves as a consequence of salinity variations, though in most cases the relationship between ornamentation and salinity seemed present. Carbonel (1980) suggests an alternative explanation, but confirming it would require measuring the $\mathrm{Mg}^{2+}$ and $\mathrm{Ca}^{2+}$ water contents.

\section{Sieve-plates}

The valves of $C$. torosa have also been studied concerning the form of their sieve pores. According to Rosenfeld \& Vesper (1977) there is a relationship between salinity and the shape of the sieve pores, 


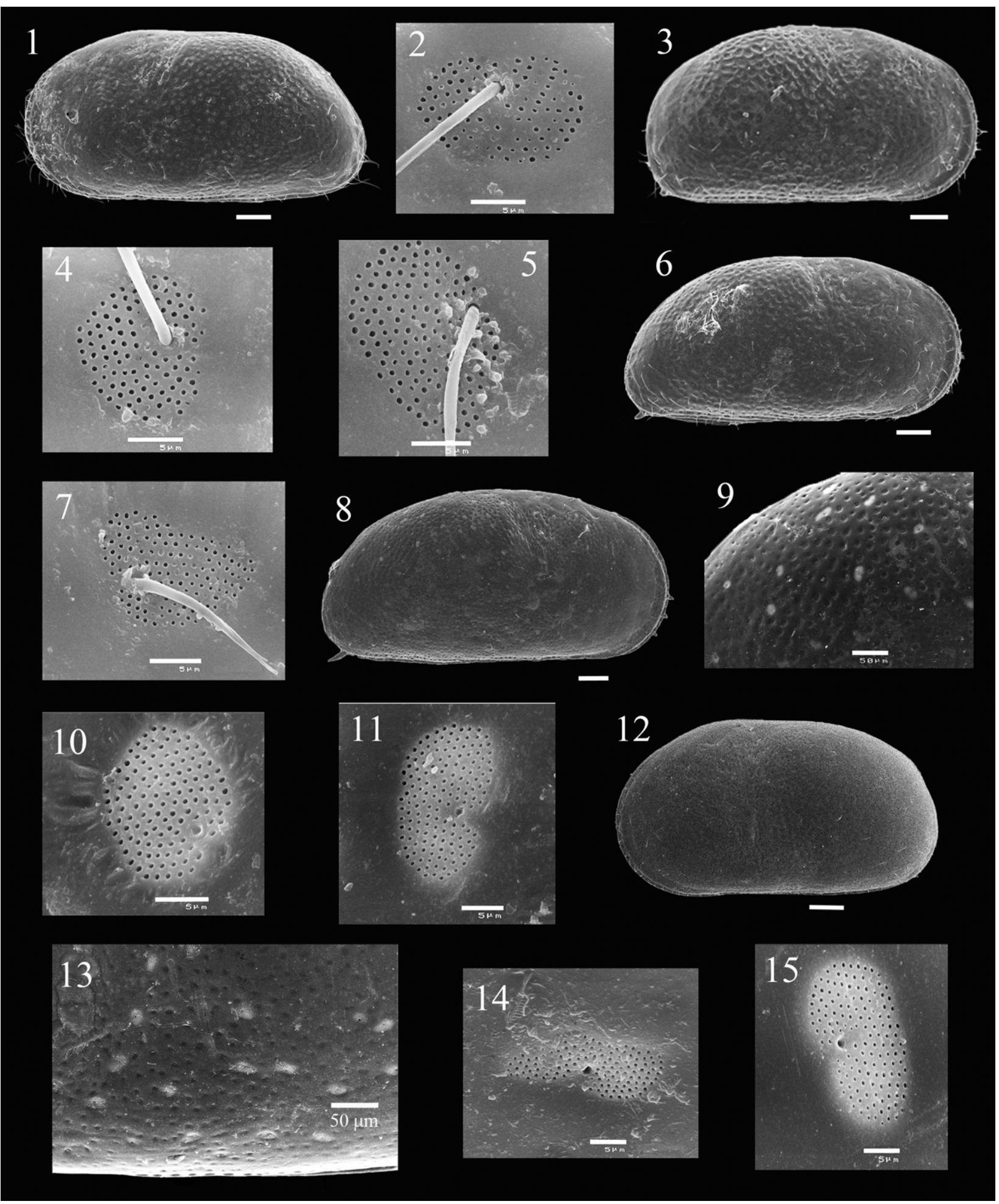

Fig. 17. Cyprideis torosa (Jones, 1850) in Sado estuary (1-7) and Melides lagoon (8-15). 1, 2. Cyprideis torosa, LV, external, $\mathrm{m}$; punctated valve; Sado estuary, CAR-P1 spr.; (2) showing round sieve pore. 3-5. Cyprideis torosa, RV, external, f; reticulated valve; Sado estuary, CAR-P1 spr.; $(4,5)$ showing round sieve pore. 6, 7. Cyprideis torosa, RV, external, m; punctated valve; Sado estuary, CAR-P1 spr.; (7) showing irregular sieve pore. 8-10. Cyprideis torosa, RV, external, m; punctated valve; Melides lagoon, MEL6 wint.; (9) sieve pores (in white) general view, postero-dorsal zone; (10) showing round sieve pore; (11) showing round to oblong sieve pore. 12-15. Cyprideis torosa, LV, external, f; smooth valve; Melides lagoon, MEL6 wint.; (13) sieve-pores (in white) general view, ventral zone. (14) showing irregular sieve pore; (15) showing round to oblong sieve pore. C, carapace; LV, left valve; RV, right valve; f, female; m, male; spr., spring; wint., winter; scale bar $100 \mu \mathrm{m}$, except when indicated.

which varies from round, through oblong to irregular, with the proportion of rounded-shaped sieve pores decreasing when salinity increases. The authors provide diagrams allowing estimation of palaeosalinity from the proportions of rounded/oblong/irregular sieve pores in fossil C. torosa valves, based on modern samples from water habitats with known salinities (marginal-marine and lakes from Germany, Denmark and Israel). This analysis needs very well-preserved and clean adult valves and is time-consuming with 
the scanning electron microscope (SEM), whether we do complete (photo)cartography of the valves or if we only count the different sieve-pore types. Few studies until now have checked the method, probably because it is time-consuming (e.g. Gliozzi \& Mazzini 1998; Keatings et al. 2007; Frenzel unpublished data, in Pint et al. 2012, p. 339). Gliozzi \& Mazzini (1998) studied Early Pleistocene material from brackish marshes in Italy; Frenzel (2009, in Pint et al. 2012) studied Recent material from marginal-marine settings of the Baltic Sea coast; in both works the results seem to confirm Rosenfeld \& Vesper's observations. In Keatings et al. (2007) the studied material comes from Lake Qarun, Egypt, with athalassic waters; the results were clearly unreasonable. As concluded by Keatings et al. (2007), Rosenfeld \& Vesper's (1977) calibration is only useful if the water chemistry of the studied habitat is inside the range of site types used by these authors, which is the case of marginal-marine environments.

We tried to analyse several empty valves from Sado estuary, CAR transect (Fig. 17:1-17:7) and from Melides lagoon, MEL 6 (Fig. 17:8-17:15) without counting the total number of each type of sieve pore present in a valve, as it takes too much SEM time. The CAR valves come from the tidal flat, sample P1 spr., with salinity of the interstitial waters $c .30$; in Melides lagoon the salinity at the bottom of the water mass in site 6 was $c$. 15. With this quick observation, we realized that in these adult valves, almost smooth, punctate or reticulate, the round pores were dominant in the central part of the valves, while in the periphery the oblong pores predominated (Fig. 17:9 and 17:13). However, distinguishing the different sieve-pore types was not always easy, especially the round from the oblong ones; so, to assess the proportions of the three types of sieve pores is a subjective task, which could be more accurate using machine image-analysis.

Recent studies of the shape, size and density of the sieve pores on the valves of a freshwater species from Turkey (Cabral et al. 2014) also show a slight dominance of oblong pores along the extreme periphery of the valve. For this Turkish species (Gomphocythere besni Külköylüoglu et al.), a map of the distribution of the sieve plates on a whole valve was made, using $c$. 72 SEM photos for a single valve, which allowed a grid-count of all the valve's sieve pores. This objective method applied to C. torosa would allow trustworthy distinction among the three types of sieve pores and comparison between the two species. This would be valuable for establishing the relationship between sieve-pore shape and salinity.

\section{Conclusions}

In mainland Portugal C. torosa lives in marginal-marine zones, namely lagoons and estuaries: Melides lagoon, where it is very abundant and the dominant species; and the large Tejo and Sado estuaries, in their tidal flats and low marshes of sheltered areas with almost lagoonal dynamics, where it becomes frequent. It is never present in estuaries with pronounced channelled morphology, which promotes strong tidal currents.

Cyprideis torosa was never found alive in the high marsh zone reached by marine water only during high tide, indicating that it can endure only short emersion times. It is more abundant in sediments in autumn/winter than in spring/summer, which is in accordance with its life-cycle. In agreement with previous authors our data show that this species prefers soft mud to a sandy-mud substrate and is highly euryhaline and eurythermic; in Portuguese estuaries, it was found living in a salinity range of 19.0-34.1 and a temperature range of $13.3-21.7^{\circ} \mathrm{C}$, in sediment interstitial water; in the Melides lagoon, the salinity range varies from 4.1 to 15.1 and the temperature from 10.8 to $14^{\circ} \mathrm{C}$ at the bottom of the water mass, near the sampling sites, during winter. It prefers slightly alkaline waters with $\mathrm{pH}>7$ and tolerates hypoxic conditions, supporting a concentration of dissolved oxygen as low as $0.09 \mathrm{mg}^{-1}$.
Cyprideis torosa occurs in different ostracod assemblages: in Melides lagoon associated with fresh- to slightly brackish-water species and rare brackish species; in the estuaries associated with typical brackish species.

It is clear that the distribution of C. torosa is controlled by the hydrodynamics of the water body, emersion time and substrate, more than by salinity, temperature or dissolved oxygen, all of which show large variation. This is evident in the studied estuaries, where large amounts of data were available; for modern lagoons, where data are less abundant (only one lagoon, in winter season, was studied), studies must continue in other seasons and locations to reinforce these conclusions. The effect of water chemistry is apparently more important in determining differences in both carapace ornamentation and shape of the sieve pores, but this would require further study, which is a possible new research line.

In the Holocene $C$. torosa is generally present through the borehole records, concentrated during the late Early to the early Late Holocene, particularly in sediments deposited in lagoonal environments, where it is very abundant and generally the dominant species, and in estuaries, with lower abundance. The associated species vary according to the environment, being similar to those found nowadays. Generally, C. torosa presents the same ecological preferences (substrate, lagoon v. estuary preference, similar assemblages) in the Holocene and in modern times.

\section{Acknowledgements and Funding}

We thank the Master student Inês Ferreira Nunes (Department of Geology, University of Lisbon) for help with field work in Melides lagoon, Telmo Nunes (Unidade de Microscopia, FCUL, Portugal) for taking the SEM photos and Anabela Cruces (Department of Geology, University of Lisbon) for general information about Melides lagoon. Dan Danielopol (Karl-Franzens Universit, Graz) and John Whittaker (Natural History Museum, London) carefully reviewed this manuscript and provided valuable suggestions. Alan Lord encouraged us to publish the data accumulated during the last decade.

This paper is a contribution to Projects Storminess and Environmentally Sensitive Atlantic Coastal Areas of the European Union (|ENV4-CT97-0488, 1997/2000, CeGUL - European Comission) and PRAXIS/PCNA/P/CTE/9/1996, PDCTM/P/MAR/15231/1999, POCTI/CTA/45185/2002 (MicroDyn), PTDC/ CTE-GEX/65789/2006 (PaleoNaz), PTDC/CTE-GIX/105370/2008 (WesTLog), funded by the Fundação para a Ciência e Tecnologia - FCT (Portugal).

\section{Scientific editing by Alan Lord}

\section{References}

Alday, M., Cearreta, A., Cachão, M., Freitas, M.C., Andrade, C. \& Gama, C. 2006. Micropalaeontological record of Holocene estuarine and marine stages in the Corgo do Porto rivulet (Mira River, SW Portugal). Estuarine, Coastal and Shelf Science, 66, 532-543.

Almeida, I.M., Andrade, C., Freitas, M.C., Moreno, J., Cabral, M.C., Craveiro, S. C. \& Marques, M.S.F. 2009. Holocene paleoenvironmental evolution of the Lisbon downtown area as recorded in the Esteiro de Baixa sediments - first results. Journal of Coastal Research, Special issue 56, 574-578.

Âmbar, I., Fiúza, A., Sousa, F. \& Lourenço, I. 1980. General circulation in the lower Sado estuary under drought conditions. Proceedings of Actual Problems in Oceanography in Portugal. JNICT/Nato, Lisboa 1982, 97-107.

Antunes, M.T., Bizon, G., Nascimento, A. \& Pais, J. 1981. Nouvelles données sur la datation des dépôts miocènes de l'Algarve (Portugal), et l'évolution géologique regionale. Ciências da Terra, 6, 153-168.

Antunes, M.T., Mein, P., Nascimento, A. \& Pais, J. 1986. Le gisement pleistocène de Morgadinho, en Algarve. Ciências da Terra, 8, 9-22.

ARH Tejo 2011. The Tagus River Basin District - Portugal. Case Study. Ministério da Agricultura, Mar, Ambiente e Ordenamento do Território/ Administração da Região Hidrográfica do Tejo I.P (ed.). United Nations World Water Development Report. World Water Assessment Programme (UNESCO).

Athersuch, J., Horne, D.J. \& Whittaker, J.E. 1989. Marine and Brackish Water Ostracods (Superfamilies Cypridacea and Cytheracea). Synopses of the British Fauna, 43. Linnean Society and Estuarine and Brackish-Water Sciences Association. E.J. Brill, Leiden.

Barbeito-Gonzàlez, P.J. 1971. Die Ostracoden des Küstenbereiches von Naxos (Griechenland) und ihre Lebensbereiche. Mitteilungen aus dem Hamburgischen zoologischen Museum und Institut, 67, 255-326.

Bettencourt, A., Ramos, L., Gomes, V., Dias, J.M.A., Ferreira, G., Silva, M. \& Costa, L. 2003. Estuários Portugueses. INAG -Ministério das Cidades, Ordenamento do Território e Ambiente. Lisboa. 
Bodergat, A.-M., Rio, M. \& Andréani, A.-M. 1991. Composition chimique et ornementation de Cyprideis torosa (Crustacea, Ostracoda) dans le domaine paralique. Oceanologica Acta, 14, 505-514.

Bonaduce, G., Ciampo, G. \& Masoli, M. 1976. Ostracods as ecological and palaeoecological indicators. Publicazioni della Stazione Zoologica di Napoli, 40, 1-154.

Cabral, M.C. \& Loureiro, I.M. 2013. Overview of Recent and Holocene ostracods (Crustacea) from brackish and marine environments of Portugal. Journal of Micropalaeontology, 32, 135-159, http://doi.org/10.1144/jmpaleo2012-019

Cabral, M.C., Colin, J.-P. \& Carbonel, P. 2004. First occurrence of the genus Zonocypris (Ostracoda) in the Pleistocene of Western Europe (Portugal). Journal of Micropalaeontology, 23, 105-106, http://doi.org/10.1144/jm.23.2.105

Cabral, M.C., Colin, J.-P. \& Carbonel, P. 2005a. Espèces pléistocènes de la famille Darwinulidae Brady et Norman, 1889 (Ostracodes), en Algarve, sud Portugal. Revue de micropaléontologie, 48, 51-62.

Cabral, M.C., Colin, J.-P. \& Carbonel, P. 2005b. First occurrence of the genus Sclerocypris Sars, 1924 (Ostracoda) in the ? Pleistocene of Western Europe (Portugal). Journal of Micropalaeontology, 24, 169-170, http://doi.org/10. 1144/jm.24.2.169

Cabral, M.C., Freitas, M.C., Andrade, C. \& Cruces, A. 2006. Coastal evolution and Holocene ostracods in Melides lagoon (SW Portugal). Marine Micropaleontology, 60, 181-204.

Cabral, M.C., Freitas, M.C., Andrade, C., Moreira, S. \& Cruces, A. 2011. Holocene ostracods of Pederneira (Nazaré, Portugal), a structurally-segmented infilled lagoon. Joannea Geologie und Paläontologie, 11, 36-38.

Cabral, M.C., Danielopol, D.L. et al. 2014. Sieve-type pores on the valves of Timiriaseviinae ostracods. Their interest for the systematics of selected taxa. ROLF 2014, 25éme Réunion des Ostracodes de Langue Française. Université de Perpignan Via Domitia, Abstracts, 5-7.

Carbonel, P. 1980. Les ostracodes et leur interêt dans la définition des écosystèmes estuariens et de plateforme continentale. Essais d'application à des domaines anciens. Mémoires de l'Institut de Géologie du Bassin d'Aquitaine, 11, 1-350.

Cearreta, A., Cachão, M., Cabral, M.C., Bao, R. \& Ramalho, M.J. 2003. Lateglacial and Holocene environmental changes in Portuguese coastal lagoons 2: microfossil multiproxy reconstruction of the Santo André coastal area. The Holocene, 13, 447-458.

Fatela, F., Moreno, J., Leorri, E. \& Corbett, R. 2014. High marsh foraminiferal assemblages response to intra-decadal and multi-decadal precipitation variability, between 1934 and 2010 (Minho, NW Portugal). Journal of Sea Research, 93, 118-132.

Freitas, M.C., Andrade, C. \& Cruces, A. 2002. The geological record of environmental changes in southwestern Portuguese coastal lagoons since the Lateglacial. Ouaternary International, 93-94, 161-170.

Freitas, M.C., Andrade, C. et al. 2003. Lateglacial and Holocene environmental changes in Portuguese coastal lagoons: 1. The sedimentological and geochemical records of the Santo André coastal area (SW Portugal). The Holocene, 13, 433-446.

Frenzel, P., Schulze, I. \& Pint, A. 2012. Noding of Cyprideis torosa valves (Ostracoda) - a proxy for salinity? New data from field observations and a long-term microcosm experiment. International Review of Hydrobiology, 97, 314-329.

Gliozzi, E. \& Mazzini, I. 1998. Palaeoenvironmental analysis of Early Pleistocene brackish marshes in the Rieti and Tiberino intrapenninic basins (Latium and Umbria, Italy) using ostracods (Crustacea). Palaeogeography, Palaeoclimatology, Palaeoecology, 140, 325-333.

Heip, C. 1976. The life-cycle of Cyprideis torosa (Crustacea, Ostracoda). Oecologia, 24, 229-245.

Hilbich, C., Mügler, I., Daut, G., Frenzel, P., van den Borg, K. \& Mäusbacher, R. 2008. Reconstruction of the depositional history of the former coastal lagoon of Vilamoura (Algarve, Portugal): a sedimentological, microfaunal and geophysical approach. Journal of Coastal Research, 24, 83-91.

Hindson, R.A. \& Andrade, C. 1999. Sedimentation and hydrodynamic processes associated with the tsunami generated by the 1755 Lisbon earthquake. Quaternary International, 56, 27-38.

Hindson, R.A., Andrade, C. \& Parish, R. 1999. A microfaunal and sedimentary record of environmental change within the late Holocene sediments of Boca do Rio (Algarve, Portugal). Geologie en Mijnbouw, 77, 311-321.

Horne, D.J. \& Boomer, I. 2000. The role of Ostracoda in saltmarsh meiofaunal communities. In: Sherwood, B.R., Gardiner, B.G. \& Harris, T. (eds) British Saltmarshes. Forrest Text, Cardigan, for the Linnean Society of London, 182-202.

ICNB 2008. Plano de ordenamento do Parque Natural do Sudoeste Alentejano e Costa Vicentina; Estudo base - Etapa 1. Instituto da Conservação da Natureza e da Biodiversidade, Lisboa.
Jones, T.R. 1850. Description of the Entomostraca of the Pleistocene beds of Newbury, Copford, Clacton and Grays. Annals and Magazine of Natural History, series 2, 6, 25-28.

Keatings, K.W., Hawkes, I., Holmes, J.A., Flower, R.J., Leng, M.J., Abu-Zied, R. H. \& Lord, A.R. 2007. Evaluation of ostracod-based palaeoenvironmental reconstruction with instrumental data from the arid Faiyum Depression, Egypt. Journal of Paleolimnology, 38, 261-283.

Keyser, D. 2005. Histological peculiarities of the noding process in Cyprideis torosa (Jones) (Crustacea, Ostracoda). Hydrobiologia, 53, 95-106.

Kilenyi, T.I. 1972. Transient and balanced genetic polymorphism as an explanation of variable noding in the ostracode Cyprideis torosa. Micropaleontology, 18, 47-63.

Lord, A., Cabral, M.C., Dambeck, R. \& Kunst, M. 2011. Ostracod evidence for the Neolithic environment of Rio Sizandro, Portugal. Palaeobiodiversity and Palaeoenvironments, 91, 215-228.

Loureiro, I.M., Cabral, M.C. \& Fatela, F. 2009. Marine influence in ostracod assemblages of the Mira River estuary: Comparison between lower and mid estuary tidal marsh transects. Journal of Coastal Research, Special issue 56, 1365-1369.

MARETEC 2015. http://www.maretec.mohid.com/Estuarios/MenusEstuarios/ Descri\%C3\%A7\%C3\%A3o/descricao_Mira.htm (last accessed 10 September 2015).

Martins, M.J.F., Namiotko, T., Cabral, M.C., Fatela, F. \& Boavida, M.J. 2010. Contribution to the knowledge of the freshwater Ostracoda fauna in continental Portugal, with an updated checklist of Recent and Quaternary species. Journal of Limnology, 69, 160-173.

Meisch, C. 2000. Freshwater Ostracoda of western and central Europe. Spektrum Akademischer Verlag, Heidelberg.

Moreira, S., Freitas, M.C., Araújo, M.F., Andrade, C., Munhá, J., Fatela, F. \& Cruces, A. 2009. Contamination of intertidal sediments - the case of Sado estuary (Portugal). Journal of Coastal Research, Special issue 56, 1380-1384.

Nascimento, A. 1981. Les ostracodes du Miocène inférieur de la région de Lisbonne (Bassin du Tage). Ciências da Terra, 6, 189-196.

Nascimento, A. 1990. Tentative ostracode biozonation of the Portuguese Neogene. Courier Forschungsinstitut Senckenberg, 123, 181-190.

Nascimento, A. 1993. Application of abundances of Cyprideis group taxa and marine species to the reconstitution of Aquitanian paleoenvironments in the Tagus Basin (Portugal). In: McKenzie, K.G. \& Jones, P.J. (eds) Ostracoda in the Earth and Life sciences. A.A. Balkema, Rotterdam, 229-239.

Paulo, L.F. \& Moutinho, M. 1983. Systématique et distribution des ostracodes au Portugal. Publicações do Instituto de Zoologia Dr. A. Nobre, Fac. Ciências Porto, 173, 1-32.

Pint, A., Frenzel, P., Fuhrmann, R., Scharf, B. \& Wennrich, V. 2012. Distribution of Cyprideis torosa (Ostracoda) in Quaternary athalassic sediments in Germany and its application for palaeoecological reconstructions. International Review of Hydrobiology, 97, 330-355.

Ramos, S., Cowen, R.K., Ré, P. \& Bordalo, A.A. 2006. Temporal and spatial distributions of larval fish assemblages in the Lima estuary (Portugal) Estuarine coastal and Shelf Science, 66, 303-314.

Rosenfeld, A. \& Vesper, B. 1977. The variability of the sieve pores in recent and fossil species of Cyprideis torosa (Jones, 1850), as an indicator for salinity and paleosalinity. In: Löffler, H. \& Danielopol, D. (eds) Aspects of Ecology and Zoogeography of Recent and Fossil Ostracoda. Dr W. Junk, The Hague, 55-67.

Sandberg, P.A. 1964. The ostracod genus Cyprideis in the Americas. Stockholm Contributions in Geology, 12, 1-178.

Schriek van der, T., Passmore, D.G., Mugica, F.F., Stevenson, A.C., Boomer, I. \& Rolão, J. 2008. Holocene palaeoecology and floodplain evolution of the Muge tributary, Lower Tagus Basin, Portugal. Quaternary International, 189, 135-151.

Taborda, R. \& Dias, J.M.A. 1991. Análise da sobre elevação do nível do mar de origem meteorológica durante os temporais de 1978 e 1981. Geonovas, Special issue 1, 89-97.

Trog, C., Höfer, D., Frenzel, P., Camacho, S., Schneider, H. \& Mäusbacher, R. 2013. A multy-proxy reconstruction and comparison of Holocene palaeoenvironmental changes in the Alvor and Alcantarilha estuaries (southern Portugal). Revue de micropaléontologie, 56, 131-158.

Trog, C., Hempel, R., Frenzel, P. \& Mäusbacher, R. 2015. Holocene palaeoenvironmental changes in three lagoons on the Algarve coast of Portugal. Palaeobiodiversity and Palaeoenvironments, 95, 203-221.

Yassini, I. 1969. Ecologie des Associations d'Ostracodes du Bassin d'Arcachon et du littoral Atlantique. Application à l'interpretation de quelques populations du Tertiaire Aquitain. Bulletin de l'Institut de Geologie du Bassin d'Aquitaine, 7, 1-288. 